\title{
Reducing Mommy Penalties with Daddy Quotas
}

\section{Allison Dunatchik and Berkay Özcan}




\section{Reducing Mommy Penalties with Daddy Quotas}

\section{Allison Dunatchik and Berkay Özcan}

\section{CONTENTS}

1. I NTRODUCTION

2. LITERATURE REVIEW AND BACKGROUND 2

2.1. THE INTRODUCTION OF QPIP 2

2.2. Drivers of Motherhood Penalties in the Labor Market 3

2.3. Addressing Motherhood Penalties by Reducing SeX-Specialization 4

2.4. PREVIOUS RESEARCH ON THE I MPACT OF DADDY QUOTAS 4

3. DATA AND METHODS 6

3.1. DATA

3.2. IDENTIFYING TREATMENT AND CONTROL GROUPS

3.3. ECONOMETRIC SPECIFICATIONS 8

3.4. Comparing Labor Market Outcomes in Treatment and Control Groups 9

3.5. POSSIBLE THREATS TO I DENTIFICATION 10

4. RESULTS 13

4.1. LABOR FORCE PARTICIPATION 13

4.2. Full-TIME VERSUS PART-TIME EMPLOYMENT 14

4.3. UNEMPLOYMENT 16

4.4. LOG HOURLY WAGES 16

4.5. ROBUStNESS CHECKS AND ALTERNATIVE SPECIFICATIONS

5. DISCUSSION \& CONCLUSION 21

REFERENCES $\quad 23$

$\begin{array}{ll}\text { APPENDIX } & 27\end{array}$ 


\section{Centre for Analysis of Social Exclusion}

The Centre for Analysis of Social Exclusion (CASE) is a multi-disciplinary research centre based at the London School of Economics and Political Science (LSE), within the Suntory and Toyota International Centres for Economics and Related Disciplines (STICERD). Our focus is on exploration of different dimensions of social disadvantage, particularly from longitudinal and neighbourhood perspectives, and examination of the impact of public policy.

In addition to our discussion paper series (CASEpapers), we produce occasional summaries of our research in CASEbriefs, and reports from various conferences and activities in CASEreports. All these publications are available to download free from our website.

For further information on the work of the Centre, please contact the Centre Manager, Jane Dickson, on:

Telephone: UK+20 79556679

Email: j.dickson@lse.ac.uk

Web site: http://sticerd.Ise.ac.uk/case

(C) Allison Dunatchik

Berkay Özcan

All rights reserved. Short sections of text, not to exceed two paragraphs, may be quoted without explicit permission provided that full credit, including (c) notice, is given to the source. 


\title{
Editorial note
}

Berkay Özcan is an Associate at CASE and an Associate Professor in the Department of Social Policy and the School of Public Policy at the London School of Economics. Allison Dunatchik is a PhD Student in Sociology at the University of Pennsylvania. We are grateful to Stephen Jenkins and Nick Kingsmill for their comments on previous versions of this manuscript, which have greatly improved the paper. We would also like to thank J an Van Ours, Erik Plug, Jorge Garcia Hombrados who provided invaluable analytical advice and expertise. Finally, we thank the participants of the 2016 Annual Meeting of the Population Association of America and the 2016 Annual Conference of the European Society for Population Economics for their insightful feedback and suggestions. Errors are our own.

\begin{abstract}
This paper investigates whether daddy quotas - non-transferable paternity leave policies - mitigate motherhood penalties women face in the labor market. Using the introduction of a daddy quota in Quebec, Canada as a natural experiment, the authors employ labor force survey data to conduct a difference-in-difference estimation of the policy's impact on a range of mothers' career outcomes. The results suggest Quebec mothers exposed to the policy are 5 percentage points more likely to participate in the labor force and to work full-time, 5 percentage points less likely to work parttime, and 4 percentage points less likely to be unemployed. These results are robust to an alternative semiparametric difference-in-difference methodology and to a battery of placebo and sensitivity tests. However, the authors find that the policy's effects are largest two to three years postreform, reducing in size and significance thereafter, raising questions about the durability of such effects.
\end{abstract}

Key words: Family policy, maternal employment, work-family balance, families and work, labor force participation

JEL number: J 16 J 180

Corresponding author: adunat@sas.upenn.edu 


\section{Introduction}

The literature on gender gaps in women's labor market outcomes broadly acknowledges 'motherhood penalties' at work in depressing women's labor market attachment, wages and occupational mobility relative to men's outcomes. Such penalties are driven, at least in part, by unequal divisions of unpaid care work between men and women and by women's career interruptions around the birth of children (Bianchi, 2011; Bianchi et al., 2012, Budig et al., 2012; Harkness \& Waldfogel, 2003; Sigle-Rushton \& Waldfogel, 2007). Across OECD countries, mothers spend more time on childcare and household work and are more likely to take time out of the workforce and to work reduced hours to care for children than their male counterparts (OECD, 2012). These career interruptions often have longterm implications for other career outcomes for mothers, such as earnings, with good evidence that these penalties persist across countries and welfare regimes, although to varying degrees of severity (e.g. Budig, Misra, \& Boeckmann, 2012; Harkness \& Waldfogel, 2003; Sigle-Rushton \& Waldfogel, 2007).

Daddy quotas - or non-transferrable periods of leave reserved for fathers - may alleviate these motherhood penalties by encouraging more genderequal divisions of childcare duties within the household, by allowing mothers to dedicate more time to paid work - thereby potentially improving their positions in the labor market - and by eroding possible employer biases. However, research on the effect of daddy quotas on mothers' labor market outcomes thus far is inconclusive. The causal studies published to date focus predominantly on experiences in Scandinavian countries and produce conflicting results. For instance some studies have found that daddy quota policies improve mothers' labor market outcomes (Andersen, 2018 for Denmakr; E.-A. Johansson, 2010 for Sweden; Patnaik, forthcoming for Quebec.) while others have found no effect (Ekberg, Eriksson, \& Friebel, 2013 for Sweden) and still others have estimated negative effects on mothers' labor market outcomes (Cools, Fiva, \& Kirkeboen, 2015 for Norway).

Despite the lack of consistent evidence on the impact of these policies, nontransferrable paternity leave continues to appear on the policy agendas of governments and political parties from South Korea to Spain and to the United Kingdom (Kim, 2017; Meil, Lapuerta and Escobedo, 2017; House of Commons, 2018). As countries continue to adopt or consider adopting daddy quota policies as a means of addressing gender inequalities at work and at home, further evidence is needed to understand their effects in a variety of welfare state contexts.

This paper contributes to this effort by analyzing the impact of the implementation of a 2006 daddy quota policy in Quebec, Canada on 
mothers' labor market outcomes. Employing a difference-in-difference technique, we examine the impact of the policy on women's labor force participation, full-time and part-time employment, unemployment, and hourly wages, analyzing both average effects in the five years post implementation and how these effects develop across post-reform years. We find that exposure to the policy substantially increases mothers' likelihood of participating in the labor force and working full-time, and decreases their likelihood of working part-time and being unemployed. We find no statistically significant effect on hourly wages. Furthermore, we find that the effects of the policy are largest in 2008 and 2009, two to three years post-reform, raising question over whether the policy had lasting effects. Our findings are robust to an alternative semi-parametric difference-in-difference methodology and a battery of placebo and sensitivity tests.

We make several contributions to the ongoing debate over the effects of daddy quota policies on mothers' employment outcomes. First, our study is among the first exploring the impact daddy quota policies on mothers labor market outcomes in a context outside of the generous social welfare benefits, high levels of decommodification and egalitarianism that characterize Nordic welfare states. Second, we improve upon the only existing causal study on Quebec's daddy quota by employing a design that exploits eight years of labor force survey data, allowing us to establish with greater confidence that the identifying assumptions of our analysis hold true. Third, we explore the impact of Quebec's daddy quota on a broad range of labor market outcomes, including those that capture outcomes on the intensive margin (full-time, part-time and hourly wages) and the extensive margin (labor force participation and unemployment). Finally, we explore the development and durability of daddy quota policies, analysing how the policy's effects on a year-by-year basis five years post-reform. We discuss these in greater detail in section 2.4.

\section{Literature Review and Background}

\subsection{The I ntroduction of QPI P}

Implemented on January 1, 2006, the Regime Quebecois D'assurance Parentale or the Quebec Parental Insurance Plan (QPIP) made substantial changes to the parental leave scheme in Quebec. The policy replaced the national parental leave scheme provided by the Employment Insurance (EI) program, which entitled parents to one-year job-protected leave after the birth of a child. QPIP's provisions, detailed in Table 2.1, were designed to improve upon the national El program by reducing barriers to parents' use of parental leave provisions by increasing flexibility, eligibility and economic feasibility of taking leave as well as addressing gendered attitudes toward parental leave (Patnaik, forthcoming). 
QPIP introduced a daddy quota, where five weeks of leave (or three weeks with higher wage replacement) are reserved exclusively for fathers and cannot be transferred to mothers. While fathers had access to parental leave through the shared leave offered under El, they had no individual right to paternity leave. QPIP had a substantial impact on fathers' use of paternity leave in Quebec: Patnaik (forthcoming) estimated that exposure to the policy increased take up by 53 percentage points and increased leave duration by 3 weeks on average.

\section{Table 2.1. Comparison of QPIP and EI Benefit Details}

\begin{tabular}{|c|c|c|c|}
\hline \multirow{2}{*}{\multicolumn{2}{|c|}{ Choice of duration }} & $\mathrm{EI}$ & QPIP \\
\hline & & None & $\begin{array}{l}\text { Basic plan (BP) or special plan } \\
\text { (SP) }\end{array}$ \\
\hline \multirow[t]{2}{*}{ Maternity leave } & Duration & 15 weeks & 18 (BP) or 15 weeks (SP) \\
\hline & Benefit & $55 \%$ & 70 (BP) or $75 \%$ (SP) \\
\hline \multirow[t]{2}{*}{ Paternity leave } & Duration & None & 5 (BP) or 3 weeks (SP) \\
\hline & Benefit & None & $70(\mathrm{BP})$ or $75 \%(\mathrm{SP})$ \\
\hline \multirow[t]{2}{*}{ Parental leave } & Duration & 35 weeks & 32 (BP) or 25 weeks (SP) \\
\hline & Benefit & $55 \%$ & $\begin{array}{l}7 \text { weeks at } 70 \% \text { and } 25 \text { weeks at } \\
55 \% \text { (BP) or } 25 \text { weeks at } 75 \% \\
\text { (SP) }\end{array}$ \\
\hline \multicolumn{2}{|l|}{ Coverage } & $\begin{array}{l}\text { Employed } \\
\text { workers }\end{array}$ & $\begin{array}{l}\text { Employed and self-employed } \\
\text { workers }\end{array}$ \\
\hline \multicolumn{2}{|c|}{ Eligibility requirements } & $\begin{array}{l}600 \mathrm{hr} \text { insurable } \\
\text { earnings }\end{array}$ & Insurable income of $\$ 2000$ \\
\hline \multicolumn{2}{|c|}{$\begin{array}{l}\text { Maximum annual insurable } \\
\text { earnings }\end{array}$} & $\$ 39,000$ & $\$ 57,000$ \\
\hline
\end{tabular}

(Service Canada, 2016) Note: maximum insurable earnings caps reflect 2006 figures.

\subsection{Drivers of Motherhood Penalties in the Labor Market}

Empirical work has consistently found that mothers' wages, labor force attachment and occupational mobility suffer compared to those of nonmothers and men across OECD countries and over time (OECD, 2012; Sigle-Rushton \& Waldfogel, 2007). One theory explaining the persistence of motherhood penalties, by Becker (1985), contends that mothers' lowered labor market outcomes are the result of gender-role specialization at the household level. Because women spend time and effort on care work - and because both are finite resources - women economize on their participation in paid work, which has negative implications for their earnings and occupational mobility (Becker, 1985). 


\subsection{Addressing Motherhood Penalties by Reducing Sex- Specialization}

Research suggests that paternity leave may reduce sex-specialization within the household through a variety of mechanisms. Fathers who take paternity leave increase their skill levels as caregivers and become better equipped and therefore more likely to provide care later on in children's lives (Hook, 2010; Lammi-Taskula, 2006). Fathers' take up of paternity leave may also establish more gender egalitarian divisions of household labor within couples that endure beyond the period of leave taken (Bjornberg, 2002; Hook, 2006, 2010). Indeed, a number of studies have found that fathers who participate in paternity leave are more likely to be involved in childcare responsibilities in subsequent years compared to fathers who do not take leave (Haas \& Hwang, 2008; Nepomnyaschy \& Waldfogel, 2007; Tanaka \& Waldfogel, 2007).

The reduction of sex specialization within the household may help to erode motherhood penalties in the labor market by allowing mothers to dedicate more time and energy to paid work, reducing any real or perceived productivity losses employers associate with motherhood (e.g. Correl, Benard, \& Paik, 2007). However, fathers face a number of disincentives to taking parental leave in countries with gender-neutral leave policies (e.g. Fox, Pascall, \& Warren, 2009; Haas \& Rostgaard, 2011; OECD, 2012). Because leave benefits are often calculated as percentages of the leavetaker's wages and are capped at a modest level, it often makes more sense economically for the lower-earning parent (often the mother) to take leave (Zhelyazkova, 2013). Employers' gendered attitudes can also disincentivize men from taking parental leave available to them (Bygren \& Duvander, 2006). Daddy quotas address such obstacles by providing economic incentives to take leave and normalizing paternity leave (Haas \& Rostgaard, 2011).

\subsection{Previous Research on the I mpact of Daddy Quotas}

While previous research has identified an association between daddy quotas and more gender egalitarian divisions of labor (e.g. Brandth \& Kvande, 1998; Hook, 2010; Sullivan et al., 2009), causal studies analyzing the effects of such policies are few, find mixed results and focus predominantly on Scandinavian countries. Analyzing the 1993 implementation of a 4-week daddy quota in Norway, Kotsadam and Finseraas (2011) found that parents exposed to the policy were $50 \%$ more likely to report sharing the task of washing clothes equally between partners 15 years post reform, suggesting the policy was successful in encouraging de-specialization. However, Cools et al. (2015), studying the same reform, found no evidence that the policy benefited mothers' labor market outcomes two to five years post reform. In fact, their analysis of the policy's effects on mothers whose partner took the leave found it 
decreased mothers' annual earnings by 3.5\%, with negligible and statistically insignificant effects on employment rates, and full-time and part-time employment.

Analysing the 1995 introduction of a one-month daddy quota in Sweden, Ekberg et al. (2013) found no evidence that the policy decreased specialization within the household, finding no significant effect on fathers' likelihood of caring for a sick child eight years post reform and no effects on labor market outcomes for mothers 13 years post reform. In contrast, Johansson (2010), examining the same reform and the extension of the Swedish daddy quota to two months in 2002, found an increase in mothers' annual earnings of $6.7 \%$ for each month of leave taken by fathers, although this estimation was only significant at the $10 \%$ level.

Studying the Danish context, Andersen (2018) uses register data to analyze the impact of five parental leave systems on within couple gender wage gaps. She finds that increases in fathers' household share of leave reduces gender wage gaps by increasing mothers' wages.

A few causal studies have focused on the impact of various types of paternity leave policies apart from daddy quotas on mothers' labor market outcomes. For example several papers have studied the effects of the 2007 introduction of the Elterngeld policy in Germany, which constituted a major overhaul of parental leave provision and financing and introduced a bonus period of leave granted to parents where both parents share a portion of the leave. These papers found that the policy led to an increase in fathers' take up of parental leave (Geisler \& Kreyenfeld, 2012), that fathers who took paternity leave subsequently increased their time spent on childcare and decreased their time spent on market work (Bünning, 2015) and that the policy increased mothers' employment rates (although gains were largely concentrated in part-time work), job continuity and job quality (Kluve \& Schmitz, 2014). A recent paper analyzing the effects of a 2007 introduction of a two-week paternity leave policy in Spain on fertility via the policies impacts on the costs associated with childbearing found the policy increased mothers' labor force attachment and led to delays in subsequent childbearing (Farré \& González, 2019).

In a forthcoming paper, Patnaik (forthcoming) used cross-sectional timeuse data from the General Social Survey to investigate the impact of the Quebecois daddy quota (QPIP) on sex-specialization, finding that the policy increased fathers' time spent in unpaid domestic work by over half an hour per day and increased mothers' time spent in paid work by an hour per day four years post reform. She also found indicative evidence that the policy increased employment and full-time employment by 5\%. Patnaik's estimated effects on employment and full-time employment are similar in magnitude to our estimates, although these were only significant at the $10 \%$ level. This lack of precision may be due to her limited sample size: 
the total number of observations in the treatment group in her analysis is around 200 individuals across pre- and post-periods.

Although Patnaik's results are promising evidence of the effects of QPIP on de-specialization, a key drawback of her study design is that she only uses one pre-reform and one post-reform observation due to data availability, which is problematic for several reasons. First, this design does not allow for sufficient reassurance that the parallel trends assumption underpinning her difference-in-difference design is met. Second, it does not allow for placebo tests around the treatment year to ensure estimates identify effects of the policy rather than larger, macro trends. Third, less critically, this design also does not allow for the exploration of how the effects of the policy evolve over time.

Another drawback of Patnaik's reliance on time-use data is that although such data is useful for understanding relative time-use among members of a household, it may provide less reliable measurements of employment activities and patterns throughout the year. Because time diaries record how individuals spend their time on a given day or set of days, they unable to capture variations in working patterns throughout the year, such as seasonal employment, which may bias the results of Patnaik's analysis.

This paper improves upon the previous research on the implementation of Quebec's daddy quota, employing a difference-in-difference design that uses three years of pre-reform and five years of post-reform data, and using a labor force survey designed to capture employment patterns. In doing so, we contribute to the small but growing causal literature on daddy quotas, increasing the evidence base with which to assess the efficacy of such policies in diminishing the motherhood penalties in the labor market. We explore a broad range of labor market outcomes, including those that capture effects on the extensive margin such as labor force participation and unemployment, as well as those on the intensive margin, like full-time and part-time employment and hourly wages. Finally, unlike previous studies, we also explore how the effects of the policy develop across five years post reform to better understand when effects emerge, how they change over time and whether they endure.

\section{Data and Methods}

We use a difference-in-difference technique to estimate QPIP's impact on mothers in Quebec with respect to five labor market outcomes, comparing differences in outcomes for Quebec mothers before the reform (2003-2005) and after the reform (2007-2011), with the same difference in outcomes for mothers in the neighboring province of Ontario. 


\subsection{Data}

We conduct our analysis using annual cross-sectional public use microdata from Statistics Canada's Survey of Labour Income Dynamics (SLID) for reference years 2003 - 2011, omitting data from the treatment year (2006) as we are unlikely to observe effects of QPIP in such an early phase of implementation. SLID is an annual household survey of approximately 34,000 households (over eight waves) representing the populations of Canada's 10 provinces. The data contains rich information on respondents' labor market activities, as well as information on family characteristics. While SLID has a rotating panel design, due to concerns over sample size we use it cross-sectionally.

\subsection{I dentifying Treatment and Control Groups}

Using information on the age of the youngest person in the respondents' census family (defined as a nuclear family), we identify Quebec mothers of young children as our treatment group. This group includes Quebec mothers with children under the age of 6 in the pre-period, and those whose youngest child was born after QPIP's implementation (January 1,2006 ) in the post period. For example, in reference year 2007, our treatment group is defined as Quebec mothers whose youngest child is 1-year-old or younger while in 2008, our treatment group includes Quebec mothers whose youngest child is 2-years-old or younger.

We restrict our treatment group to married and cohabitating mothers of small children in Quebec. These women, we argue, are most likely to experience potential benefits to their careers by increased father involvement in child rearing activities, although we are unable to determine from the data whether their partners actually took up the leave available to them. We exclude mothers under the age of 18 , as these mothers are likely to be in full-time secondary education. We also exclude women where the age difference between women and the youngest child in the census family is greater than 50; as SLID does not specify the precise relationship between the youngest person in the census family and the respondent, we expect such cases to be guardianship or grandparent relationships.

A number of possible control groups were considered for this analysis, including mothers of young children from the neighboring province of Ontario, mothers of young children from British Columbia and non-mothers from Quebec. Analysis of province-level characteristics and of labor market trends prior to QPIP's implementation revealed mothers of young children from Ontario to be the best fit (see section 3.4 for a discussion of parallel trends).

Quebec and Ontario are the two most populous provinces in Canada and constitute the country's two largest regional economies. The provinces are 
comparable on a number of indicators of interest prior to 2006, such as women's labor force participation rate and unemployment rate (Statistics Canada, 2017). Prior to QPIP's 2006 implementation, they also offered parents the same parental leave scheme (the Employment Insurance program), which continued in Ontario after 2006.

\section{Table 3.1 Treatment and control group sample sizes and definitions by year}

\begin{tabular}{llll}
\hline Year & Sample definition & $\begin{array}{l}\text { Treatment } \\
\text { (Quebec) }\end{array}$ & $\begin{array}{l}\text { Control } \\
\text { (Ontario) N }\end{array}$ \\
\hline 2003 & Mothers whose youngest child is 0-5 & 408 & 645 \\
2004 & Mothers whose youngest child is 0-5 & 385 & 581 \\
2005 & Mothers whose youngest child is 0-5 & 409 & 604 \\
\hline 2007 & Mothers whose youngest child is 0-1 & 182 & 214 \\
2008 & Mothers whose youngest child is 0-2 & 279 & 327 \\
2009 & Mothers whose youngest child is 0-3 & 339 & 399 \\
2010 & Mothers whose youngest child is 0-4 & 365 & 432 \\
2011 & Mothers whose youngest child is 0-5 & 395 & 486 \\
\hline
\end{tabular}

We define our control group using the same criteria used to identify the treatment group. This group is comprised of partnered Ontario mothers of children under the age of six during the pre-period and mothers of children born after January 1, 2006 in the post period. Table 3.1 shows the sample sizes and definition of our treatment and control groups over our period of analysis. Our treatment group is comprised of 2,762 mothers and our control group 3,688.

\subsection{Econometric Specifications}

To test our hypothesis, we estimate a standard difference-in-difference specification:

$$
\text { Outcome }_{\mathrm{i}}=\beta_{0}+\beta_{1} \text { TREAT }_{\mathrm{i}}+\beta_{2} \text { POST }_{\mathrm{t}}+\beta_{3}\left(\text { TREAT } \times \text { POST }_{t}+\delta_{\mathrm{i}}+\lambda_{t}+\varepsilon_{\mathrm{i}}\right.
$$

The subscript $i$ indicates the individual and $t$ indicates the year. TREAT $T_{i}$ is a dummy variable equal to ' 1 ' if the respondent is a member of the treatment group, as defined in the previous section; $\boldsymbol{P O S T}_{\boldsymbol{t}}$ is a dummy equal to ' 1 ' if the observation is in the post-period; $\boldsymbol{\delta}_{\boldsymbol{i}}$ is a vector of controls; and $\boldsymbol{\lambda}_{\boldsymbol{t}}$ denotes year fixed effects. $\boldsymbol{\beta}_{3}$ is our parameter of interest and is an 
Intention to Treat (ITT) estimate of the impact of QPIP on our labor market outcomes for the population of eligible partnered Quebec mothers.

We use three specifications to estimate the effect of QPIP on each labor market outcome of interest. Model 1 follows the standard difference-indifference specification above, combining years 2007-2011 in a single post period with no control variables. Model 2 controls for factors closely associated with labor market outcomes including age, age-squared, number of children, years of education and years of work experience, which have been shown to significantly influence mothers' labor market outcomes (e.g. Waldfogel, 1998). It also includes full year dummies to account for general period effects. Finally, because we are interested in the timing of effects post-reform, Model 3 repeats Model 2, replacing the basic $(\mathrm{TREAT} \times \mathrm{POST})_{t}$ interaction with a series of interactions for each postreform year, allowing us to identify the year in which reform effects manifest:

$$
\begin{aligned}
\text { Outcome }_{i}= & \beta_{0}+\beta_{1} \text { TREAT }_{i}+\beta_{2}\left(\text { TREAT }_{\mathrm{i}} \times 2007\right) \\
& +\beta_{3}\left(\text { TREAT }_{\mathrm{i}} \times 2008\right)+\beta_{4}\left(\text { TREAT }_{\mathrm{i}} \times 2009\right)+\beta_{5}\left(\text { TREAT }_{\mathrm{i}} \times 2010\right) \\
& +\beta_{6}\left(\text { TREAT }_{\mathrm{i}} \times 2011\right)+\delta_{i}+\lambda_{t}+\varepsilon_{\mathrm{i}}
\end{aligned}
$$

We define our five outcome variables of interest using several SLID survey indicators. Labor force participation is equal to ' 1 ' if the respondent is in the labor force during the reference year. Full-time employment status, conditional on being in the labor force, is equal to ' 1 ' if the respondent is employed full-time during the reference year, and ' 0 ' if unemployed or employed part-time. Part-time employment status is equal to ' 1 ' if the respondent is employed less than full-time during the given reference year. Unemployment is equal to ' 1 ' if the respondent is unemployed at any point during the reference year and ' 0 ' if employed. Log hourly wage is based on a continuous measure of hourly wages for all respondents with earnings in the reference year and is expressed in 2002 Canadian Dollars (rebased using Statistics Canada's annual consumer price index). For analyses of binary outcome measures, our specifications use linear probability models. Detailed descriptions of these measures are available in the Appendix.

\subsection{Comparing Labor Market Outcomes in Treatment and Control Groups}

Figure 3.1 displays trends for Quebec and Ontario mothers along our four outcome variables of interest from 2003-2011 (see Appendix Table 1 for full summary statistics). Prior to QPIP's implementation in 2006, all outcome indicators develop roughly in parallel. From 2007-2011 however, we observe a steep increase in labor force participation rate and full-time employment for Quebec mothers, while these indicators remain relatively stable for Ontario mothers. We also observe a steep decline in part-time employment and unemployment among Quebec mothers. The figures on 
the raw data show that it is hard to claim that the mothers in Ontario are completely unaffected by the policy changes in Quebec as their trends also exhibit some variation, hence constituting a comparison group, rather than a true control group in the experimental sense. However, our claim in the rest of the paper, after covariate adjustments, and a battery of robustness checks including an event-study (not reported), non-parametric matching (reported in section 4.5) and a placebo test (also reported in section 4.5), is that the policy reform in Quebec changed the labor market outcomes more dramatically compared to Ontario mothers. We discuss all possible threats to identification in the next section and report a series robustness checks in section 4.5.

\section{Figure 3.1 Trends in Labor Market Outcomes for Treatment and Control Groups}
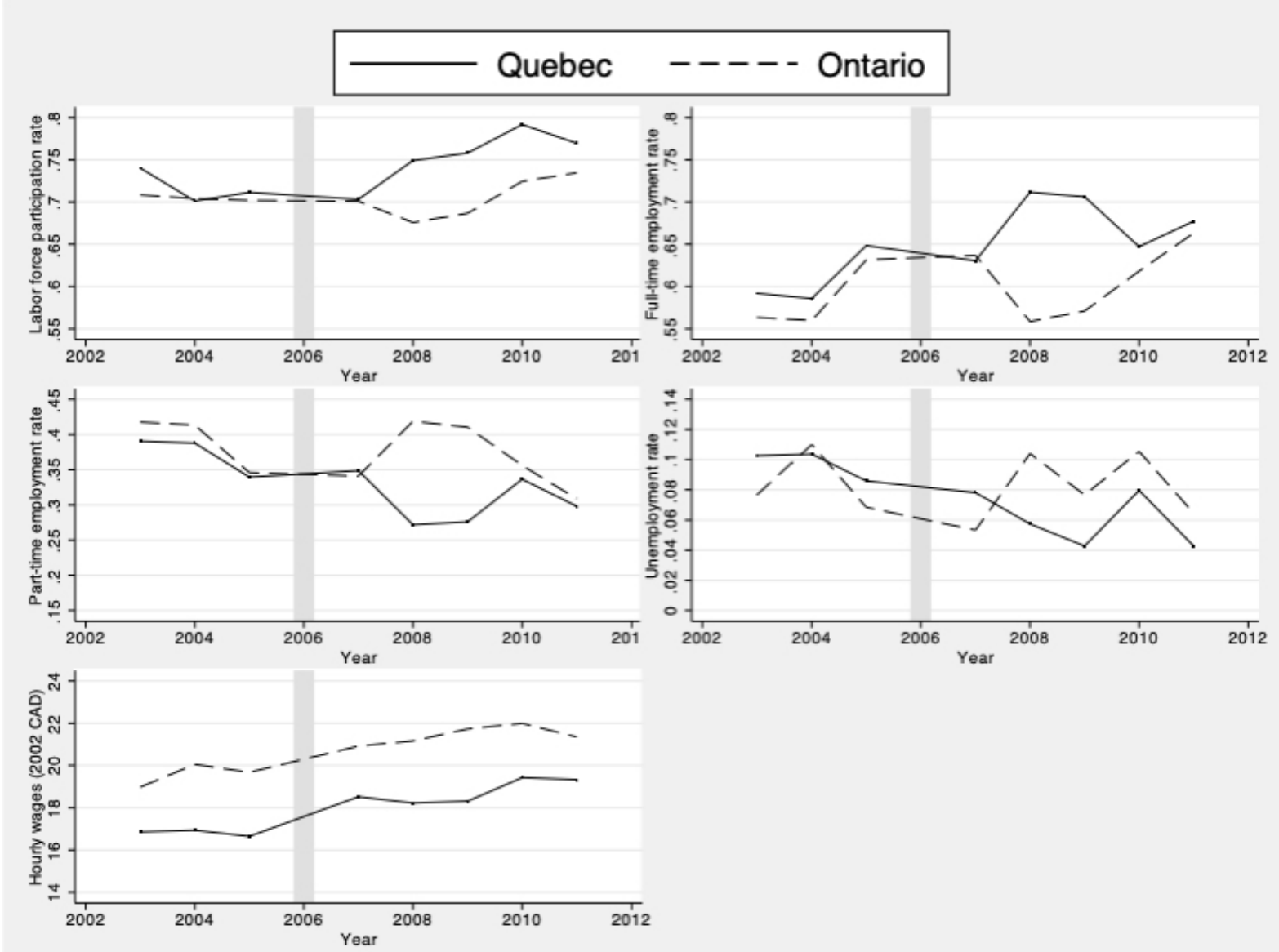

Note: vertical grey bars indicate the treatment year, 2006.

\subsection{Possible Threats to I dentification}

We identify four main threats to our identification strategy. Because our difference-in-difference model uses cross-sectional data, it relies on the assumption that there are no compositional changes in our treatment or control group over time. However, is possible that QPIP fundamentally 
changed the composition of our treatment group in the post-reform period, perhaps encouraging women to have more children, inducing different types of women to become mothers or influencing decisions about accumulating years of education or work experience prior to having children in light of the change in benefits. To assess QPIP's effect on the composition of our treatment group, we run difference-in-difference models to explore whether exposure to QPIP significantly altered the composition of Quebec mothers along observable characteristics available in SLID: number of children, years of education, years of work experience, and age. If, in fact, QPIP significantly affected the composition of our treatment group, we would expect to see a significant result in these models. However as shown in Table 3.2, we see no such effects. Although there are statistically significant differences between mothers in Quebec and Ontario on age and years of education, these do not develop differently over time following the introduction of QPIP (see Appendix Table 2 for summary statistics for these measures). This provides some assurance that QPIP did not fundamentally alter the composition of Quebec mothers along characteristics we are able to observe in SLID, although our data does not allow us to explore other possible compositional measures such as the spacing of children or women's career trajectories.

Table 3.2 I mpact of QPI P on Mothers' Characteristics

\begin{tabular}{lllllllll}
\hline & \multicolumn{2}{l}{$\begin{array}{l}\text { Years of } \\
\text { education }\end{array}$} & \multicolumn{3}{c}{$\begin{array}{l}\text { Years of work } \\
\text { experience }\end{array}$} & \multirow{2}{*}{ Age } & \multicolumn{3}{c}{$\begin{array}{l}\text { Number of } \\
\text { children }\end{array}$} \\
\cline { 2 - 9 } & $\mathrm{B}$ & SE B & B & SE B & B & SE B & B & SE B \\
\hline Treat x Post & -0.17 & 0.13 & 0.04 & 0.29 & 0.22 & 0.25 & -0.04 & 0.04 \\
Treat & $-0.50^{* *}$ & 0.1 & -0.37 & 0.22 & $-1.36^{* *}$ & 0.19 & $-0.09^{* *}$ & 0.03 \\
Post & 0.10 & 0.08 & -0.36 & 0.19 & $-0.38^{*}$ & 0.17 & -0.02 & 0.03 \\
Constant & $14.78^{* *}$ & 0.06 & $8.44^{* *}$ & 0.14 & $33.11^{* *}$ & 0.12 & $2.00^{* *}$ & 0.02 \\
N & 7,521 & & 6,450 & & 7,521 & & 7,521 & \\
\hline
\end{tabular}

Note: $* \mathrm{p}<0.05 . * * \mathrm{p}<0.01$.

Second, it may also be a concern that parents may have strategically timed the birth of a child in order to be eligible for QPIP. Details about QPIP's features and implementation date were not officially announced until March 2005, making such behavior unlikely. Still, our analysis omits data from 2006, likely accounting for any mothers who may have strategically delayed their births until QPIP's implementation.

Third, because our period of analysis encompasses the Great Recession (which in Canada was comprised of four quarters of negative GDP growth in 2009), it is possible that differential effects of the recession between Quebec and Ontario might bias our results. If Ontario were disproportionally affected by the recession, our estimated effects of QPIP may be upwardly biased in years following the recession, while if Quebec were more severely affected, we might expect our estimates to be downwards biased. To explore whether the two provinces experienced the recession differently, we run several difference-in-difference models using 
the natural logarithm of province-level GDP (in 2007 Canadian dollars) and province-level unemployment rates from Statistics Canada (2017; 2018) as outcome measures. We analyze each outcome using two models: one pooling effects in post-treatment years (Model 1) and the other breaking results down into yearly effects (Model 2 ). As shown in Table 3.3, we do not find a statistically significant effect of the recession on Quebec's GDP or unemployment rate relative to Ontario in any of our specifications, providing reassurance for our identification. We provide further reassurance that the recession has not biased our results in our robustness checks in section 4.5.

Finally, other policy changes implemented during this time might influence mothers' outcomes. In addition to adding a daddy quota, QPIP also made changes to maternity leave provisions, lowering eligibility requirements and increasing wage replacement generosity. That said, the inclusion of an individual entitlement to paternity leave reserved for fathers, where none previously existed, is the most dramatic change provided by QPIP. Indeed, analysis of the impact of the reform on parents' leave-taking behavior suggests that the effect of the policy on parents' behavior was also most dramatic among fathers. Patnaik (forthcoming) found that QPIP increased fathers' take up rates by $250 \%$ (from $21 \%$ to $74 \%$ ) and their average duration of leave by $160 \%$ (from 2.0 to 3.2 weeks) while it only increased mothers' take up rates by $16 \%$ (from $73 \%$ to $85 \%$ ) and their leave duration by $4 \%$ (from 42.5 to 44.4 weeks).

Still, because the changes in maternity leave and paternity leave were implemented simultaneously, we cannot entirely isolate the effect of each change. Research suggests that maternity leave increases mothers' employment continuity (e.g. Budig et al., 2012), raising the concern that our estimate of QPIP's effect on mothers' labor force participation may be upwardly biased. However, maternity leave may also increase specialization within the household - particularly as it increases in duration - by locating childcare responsibility within the family, and specifically among mothers. Evidence suggests that longer maternity leaves encourage part-time rather than full-time employment, carry a wage penalty and may exacerbate biased employer perceptions of mothers' job commitment and competency (Budig et al., 2012; Buligescu, de Crombrugghe, Menteşoğlu, \& Montizaan, 2009; Morgan \& Zippel, 2003; Morgenroth \& Heilman, 2017; Pettit \& Hook, 2009). Thus, QPIP's extension of maternity leave may lead to an underestimation of the effect a daddy quota on these outcomes through this analysis, if increased maternity leave operates in the reverse direction to the effects of a daddy quota.

Researching further changes to Quebec and Canadian family policy beyond QPIP, we find no other substantial changes during the period of analysis. Quebec has a publicly subsidized childcare system, unlike the rest of Canada, which may make it easier for Quebecois women to participate in 
paid employment (Fortin, Godbout, \& St-Cerny, 2012; Moyser \& Milan, 2018). However, this system was first implemented in 1997, nearly a decade prior to QPIP, and there were no changes to Quebec's childcare policy during our period of analysis, (2003-2011). Therefore the existence of the previous policy is unlikely to bias our results.

Table 3.3 Recession impact on (In) province GDP (2007 Canadian dollars) and unemployment rate

\begin{tabular}{|c|c|c|c|c|c|c|c|c|}
\hline & \multicolumn{4}{|l|}{$(\operatorname{In})$ GDP } & \multicolumn{4}{|c|}{ Unemployment } \\
\hline & Model 1 & & Model 2 & & Model 1 & & Model 2 & \\
\hline & B & SE B & B & SE B & B & SE B & B & SE B \\
\hline Treat $x$ Post & 0.02 & 0.02 & & & -1.77 & 0.83 & & \\
\hline Treat & $-0.67 * *$ & 0.02 & $-0.67 * *$ & 0.02 & $1.83^{*}$ & 0.65 & $1.83 *$ & 0.73 \\
\hline Post & $0.05^{* *}$ & 0.02 & $0.05 *$ & 0.02 & 0.97 & 0.58 & 0.97 & 0.65 \\
\hline Treat x 2007 & & & -0.00 & 0.03 & & & -2.27 & 1.22 \\
\hline Treat x 2008 & & & 0.02 & 0.03 & & & -2.37 & 1.22 \\
\hline Treat x 2009 & & & 0.01 & 0.03 & & & -0.97 & 1.22 \\
\hline Treat x 2010 & & & 0.03 & 0.03 & & & -1.57 & 1.22 \\
\hline Treat x 2011 & & & 0.05 & 0.03 & & & -1.67 & 1.22 \\
\hline Constant & $13.25^{* *}$ & 0.01 & $13.25^{* *}$ & 0.01 & $6.77^{* *}$ & 0.46 & $6.77 * *$ & 0.51 \\
\hline $\mathrm{N}$ & 16 & & 16 & & 16 & & 16 & \\
\hline
\end{tabular}

Note: $* \mathrm{p}<0.05 . * * \mathrm{p}<0.01$. Analysis based on data from CANISM table 384-0038 and CANISM table 282-0002.

\section{Results}

\subsection{Labor Force Participation}

Table 4.1 reports the linear probability model results from our differencein-difference specifications estimating the impact of QPIP on Quebec mothers' labor force participation.

In Model 2, we estimate the policy increases Québécois mothers' likelihood of being in the labor force by 5 percentage points compared to the Ontarian mothers in our control group after the policy change over the five years. This 5 percentage point increase equates to a 6 percent increase from our expected labor force participation among Quebec mothers of $75 \%$. In Model 3 however, we find that the effect of the reform varies over time. We observe no effect in 2007, perhaps indicating lagged effects of the policy. We find mothers exposed to the policy are 8 percentage points more likely to participate in the labor force in 2008, relative to expectations in the absence of the policy, and 7 percentage points more likely in 2009. In 2010 and 2011, however we find statistically non-significant - although still positive - effects. 
Table 4.1. I mpact of QPI P on Mothers' Labor Force Participation, LPM Results $N=6,450$

\begin{tabular}{lllllll}
\hline & Model 1 & \multicolumn{3}{l}{ Model 2 } & Model 3 \\
\cline { 2 - 7 } & B & SE B & B & SE B & B & SE B \\
\hline Treat x Post & 0.04 & 0.02 & $0.05^{*}$ & 0.02 & & \\
Treat & 0.01 & 0.02 & 0.02 & 0.02 & 0.02 & 0.02 \\
Post & 0.00 & 0.02 & -0.04 & 0.03 & & \\
Treat x 2007 & & & & & 0.00 & 0.05 \\
Treat x 2008 & & & & $0.08 *$ & 0.04 \\
Treat x 2009 & & & & $0.07^{*}$ & 0.03 \\
Treat x 2010 & & & 0.06 & 0.03 \\
Treat x 2011 & & & & 0.02 & 0.03 \\
Controls & No & & Yes & & Yes & \\
R2 & 0.00 & & 0.16 & & 0.16 & \\
F & $5.81^{* * *}$ & & $87.21^{* *}$ & & $68.01^{* *}$ & \\
\hline
\end{tabular}

Note: Controls include full year dummies, age, age-squared and number of children years of education and years of work experience; $* p<0.05$. $* * p<0.01$.

\subsection{Full-time versus Part-time Employment}

Table 4.2 and Table 4.3 present the results from our specifications estimating the impact of QPIP on the likelihood that Quebec mothers report full-time and part time employment. In Model 2, we find a significant effect across both outcomes: mothers exposed to the policy are 5 percentage points more likely to work full-time and 5 percentage points less likely to work part time in the post-reform period relative to Ontario mothers. These results constitute an $8 \%$ increase in full-time employment over the expected full-time employment rate in the absence of QPIP, 64.7\%, and a $16 \%$ decrease from the expected part-time employment rate, $33.0 \%$. Breaking these results down by year in Model 3 we find virtually no effect in 2007 on either outcome. We find a statistically a significant increase in full-time employment of 14 percentage points relative to expected outcomes in the absence of the policy, and a decrease in part-time employment of the same magnitude in 2008 and 2009 but in 2010 and 2011, we find negligible, non-significant effects across outcomes. Possible explanations for the dissipation of effects in 2010 and 2011 are considered in the discussion section.

Taken together, these results suggest that the increase in mothers' labor force participation largely manifests as full-time employment rather than as part-time employment. This distinction is important as part-time employment often translates to lower pay and fewer opportunities for career advancement (Manning \& Petrongolo, 2008). 
Table 4.2 I mpact of QPI P on Mothers' Full-Time Employment, LPM Results $N=5,308$

\begin{tabular}{|c|c|c|c|c|c|c|}
\hline & \multicolumn{2}{|c|}{ Model 1} & \multicolumn{2}{|l|}{ Model 2} & \multicolumn{2}{|l|}{ Model 3} \\
\hline & $\mathrm{B}$ & SE B & $\mathrm{B}$ & SE B & $B$ & SE B \\
\hline Treat x Post & 0.04 & 0.03 & $0.05^{*}$ & 0.03 & & \\
\hline Treat & 0.02 & 0.02 & 0.03 & 0.02 & 0.03 & 0.02 \\
\hline Post & 0.03 & 0.02 & 0.05 & 0.03 & & \\
\hline Treat x 2007 & & & & & -0.01 & 0.05 \\
\hline Treat x 2008 & & & & & $0.14 * *$ & 0.04 \\
\hline Treat x 2009 & & & & & $0.14 * *$ & 0.04 \\
\hline Treat $\times 2010$ & & & & & 0.02 & 0.04 \\
\hline Treat x 2011 & & & & & -0.01 & 0.04 \\
\hline Controls & No & & Yes & & Yes & \\
\hline $\mathrm{R} 2$ & & 01 & & 0.13 & & 0.13 \\
\hline $\mathrm{F}$ & $9.38^{*}$ & & $57.34 * *$ & & $46.06 * *$ & \\
\hline
\end{tabular}

Table 4.3. I mpact of QPIP on Mothers' Part-Time Employment, LPM Results $\mathbf{N}=5,130$

\begin{tabular}{|c|c|c|c|c|c|c|}
\hline & \multicolumn{2}{|l|}{ Model 1} & \multicolumn{2}{|l|}{ Model 2} & \multicolumn{2}{|l|}{ Model 3} \\
\hline & $\mathrm{B}$ & SE B & $\mathrm{B}$ & SE B & $\mathrm{B}$ & SE B \\
\hline Treat $x$ Post & -0.04 & 0.03 & $-0.05^{*}$ & 0.03 & & \\
\hline Treat & -0.02 & 0.02 & -0.03 & 0.02 & -0.03 & 0.02 \\
\hline Post & -0.03 & 0.02 & -0.05 & 0.03 & & \\
\hline Treat x 2007 & & & & & 0.01 & 0.05 \\
\hline Treat x 2008 & & & & & $-0.14 * *$ & 0.05 \\
\hline Treat x 2009 & & & & & $-0.14 * *$ & 0.04 \\
\hline Treat $\times 2010$ & & & & & -0.02 & 0.04 \\
\hline Treat $\times 2011$ & & & & & 0.01 & 0.04 \\
\hline Controls & No & & Yes & & Yes & \\
\hline $\mathrm{R} 2$ & & 0.00 & & 0.11 & & 0.11 \\
\hline $\mathrm{F}$ & $8.73 * * *$ & & $44.52 * *$ & & $36.01 * *$ & \\
\hline
\end{tabular}




\subsection{Unemployment}

Shown in Table 4.4, we find that QPIP decreased the likelihood that Quebec mothers are unemployed by 4 percentage points relative to our expectations in the absence of the policy according to our Model 2 specification. This is a substantial effect, constituting around $10 \%$ decrease from the expected unemployment rate among mothers on average per year in the absence of the policy, 9.3\%. In Model 3, we find no effect on unemployment in 2007 and a reduction in the likelihood of being unemployed by 7 percentage points in 2008 and 6 percentage points in 2009. In 2010 and 2011 we continue to find negative effects, although these are not statistically significant.

Table 4.4. I mpact of QPI P on Mothers' Unemployment, LPM Results $\mathrm{N}=4,655$

\begin{tabular}{lllllll}
\hline & Model 1 & \multicolumn{3}{l}{ Model 2 } & \multicolumn{3}{l}{ Model 3 } \\
\cline { 2 - 7 } & B & SE B & B & SE B & B & SE B \\
\hline Treat x Post & $-0.04^{*}$ & 0.02 & $-0.04^{* *}$ & 0.02 & & \\
Treat & 0.01 & 0.01 & 0.01 & 0.01 & 0.01 & 0.01 \\
Post & -0.00 & 0.01 & -0.03 & 0.02 & & \\
Treat x 2007 & & & & & 0.00 & 0.03 \\
Treat x 2008 & & & & & $-0.07^{*}$ & 0.03 \\
Treat x 2009 & & & & $-0.06^{*}$ & 0.02 \\
Treat x 2010 & & & & -0.05 & 0.03 \\
Treat x 2011 & & & & -0.04 & 0.02 \\
Controls & No & & Yes & & Yes & \\
R2 & 0.00 & & 0.03 & & 0.03 & \\
F & $4.39 * *$ & & $6.55^{* *}$ & & $5.24 * *$ & \\
\hline
\end{tabular}

Note: Controls include full year dummies, age, age-squared and number of children years of education and years of work experience; $* p<0.05$. ** $p<0.01$.

\subsection{Log Hourly Wages}

Finally, we explore QPIP's impact on mothers' hourly wages. Our ex ante expectation is that by encouraging a more gender equal division of household labor, QPIP would allow mothers to devote more time and effort to paid labor, which, over time should increase their financial compensation. However, as shown in Table 4.5, our results do not support this hypothesis. We find positive but statistically non-significant effects on hourly wages across our models. 
Table 4.5. I mpact of QPI P on Mothers' Hourly Wages, OLS Results $\mathrm{N}=\mathbf{4 , 6 6 5}$

\begin{tabular}{lllllll}
\hline & Model 1 & \multicolumn{3}{c}{ Model 2 } & \multicolumn{3}{l}{ Model 3 } \\
\cline { 2 - 6 } & B & SE B & B & SE B & B & SE B \\
\hline Treat x Post & 0.02 & 0.03 & 0.04 & 0.02 & & \\
Treat & $-0.13^{* *}$ & 0.02 & $-0.06^{* *}$ & 0.02 & $-0.06 * *$ & 0.02 \\
Post & $0.10^{* *}$ & 0.02 & $0.08^{*}$ & 0.03 & & \\
Treat x 2007 & & & & & 0.03 & 0.05 \\
Treat x 2008 & & & & 0.02 & 0.04 \\
Treat x 2009 & & & & 0.03 & 0.04 \\
Treat x 2010 & & & & 0.06 & 0.04 \\
Treat x 2011 & & & & 0.06 & 0.03 \\
Controls & No & & Yes & & Yes & \\
R2 & 0.03 & & 0.34 & & 0.34 & \\
F & $41.74 * * *$ & & $170.01 * * *$ & $132.79 * * *$ & \\
\hline
\end{tabular}

Note: Controls include full year dummies, age, age-squared and number of children years of education and years of work experience; $* p<0.05 . * * p<0.01$.

\subsection{Robustness Checks and alternative specifications}

We run a series of robustness checks using our Model 2 specification. First, we run a semi-parametric difference-in-difference model for each outcome variable. Rather than using Ontario mothers as a control group, we use kernel propensity score matching to construct a group of mothers with children age 5 and under from across Canada who are comparable to Quebec mothers in age, years of education and number of children.

The results from these specifications, shown in Table 4.6, strongly support our main results. We find that exposure to QPIP increases likelihood of labor force participation by 6 percentage points in the post period relative to expected outcomes based on time tends of comparable mothers in our constructed control group. We find the policy also increases Quebec mothers' likelihood of working full-time by 4 percentage points and decreases the likelihood of working part-time by 4 percentage points and unemployment by 2 percentage points. Again, we find no significant effect on wages. 


\section{Table 4.6 Robustness Check 1: Semi-Parametric Difference-in- Difference Models}

\begin{tabular}{|c|c|c|c|c|c|c|c|c|c|c|}
\hline & \multicolumn{2}{|c|}{$\begin{array}{l}\text { Labor force } \\
\text { participation }\end{array}$} & \multicolumn{2}{|c|}{$\begin{array}{l}\text { Full-time } \\
\text { employment }\end{array}$} & \multicolumn{2}{|c|}{$\begin{array}{l}\text { Part-time } \\
\text { employment }\end{array}$} & \multicolumn{2}{|c|}{$\begin{array}{l}\text { Unemploy- } \\
\text { ment }\end{array}$} & \multicolumn{2}{|c|}{$\begin{array}{l}\text { (In) Hourly } \\
\text { wages }\end{array}$} \\
\hline & B & SE B & B & B & $B$ & SE B & B & SE B & $\mathrm{B}$ & SE B \\
\hline Estimator & $0.06 * *$ & 0.02 & $0.04 *$ & 0.02 & $-0.04 *$ & 0.02 & $-0.02 *$ & 0.01 & -0.01 & 0.02 \\
\hline $\mathrm{R} 2$ & 0.16 & & 0.12 & & 0.10 & & 0.03 & & 0.32 & \\
\hline $\mathrm{N}$ & 13,260 & & 10,635 & & 10,307 & & 9,197 & & 9,240 & \\
\hline
\end{tabular}

Note: Models include full year dummies and controls for age, age-squared and number of children years of education and years of work experience; $* p<0.05$. $* * \mathrm{p}<0.01$.

Next, we run Model 2 using 2004 as a placebo treatment year. Our preperiod is therefore defined as 2002-2003 and our post-period is defined as 2005-2011. If QPIP's implementation in 2006 is truly driving the effects we detect in our main specifications, we should not find significant effects under this placebo specification. Indeed, as shown in Table 4.7, none of our Treat x Post 2004 interactions is statistically significant.

Table 4.7 Robustness Check 2: Placebo Treatment Year (2004)

\begin{tabular}{|c|c|c|c|c|c|c|c|c|c|c|}
\hline & \multicolumn{2}{|c|}{$\begin{array}{l}\text { Labor force } \\
\text { participation }\end{array}$} & \multicolumn{2}{|c|}{$\begin{array}{l}\text { Full-time } \\
\text { employment }\end{array}$} & \multicolumn{2}{|c|}{$\begin{array}{l}\text { Part-time } \\
\text { employment }\end{array}$} & \multicolumn{2}{|c|}{$\begin{array}{l}\text { Unemploy- } \\
\text { ment }\end{array}$} & \multirow{2}{*}{$\begin{array}{l}(\text { In) } \\
\text { wages } \\
\text { B }\end{array}$} & \multirow{2}{*}{$\begin{array}{l}\text { Hourly } \\
\text { SE B }\end{array}$} \\
\hline & B & SE B & $B$ & SE B & B & SE B & $B$ & SE B & & \\
\hline Estimator & 0.03 & 0.02 & 0.00 & 0.03 & 0.00 & 0.03 & -0.03 & 0.02 & 0.00 & 0.02 \\
\hline $\mathrm{R} 2$ & 0.17 & & 0.12 & & 0.10 & & 0.02 & & 0.33 & \\
\hline $\mathrm{N}$ & 7,459 & & 6,072 & & 5,877 & & 5,345 & & 5,365 & \\
\hline
\end{tabular}

Note: Models include full year dummies and controls for age, age-squared and number of children years of education and years of work experience; $* p<0.05$. $* * \mathrm{p}<0.01$.

Third, we explore the effect of QPIP's implementation on two alternative treatment groups: mothers of older children in Quebec and fathers of young children in Quebec. If QPIP has impacted young mothers in the way our results suggest, we should find no effect on mothers with older children, who were ineligible for the policy. Among fathers, we should find no improvements in labor market outcomes if the policy operates according to our expectations. We may, however, find a decline in fathers' labor market outcomes if QPIP is successful in reducing gendered specialization within the household.

Mothers of older children are defined as those whose youngest child is between 6-17 years of age. We define fathers of young children in the same way we defined mothers of young children in our main models: those whose youngest child is under the age of 6 in the pre-period, and those whose youngest child was born after the implementation of QPIP on January 1 , 2006 in the post-period. 
We run our Model 2 specifications on both of these alternative treatment groups. As shown in Table 4.8, among mothers of older children we do find a statistically significant effect older mothers' labor force participation of comparable magnitude to that found among mothers of young children, although we find no statistically significant impact on older mothers' fulltime or part-time employment, unemployment or hourly wages or any labor market outcomes for fathers of young children. The significant effect on labor force participation among older mothers raises some concern that the effect identified in our main specification may be picking up on a general trend for all mothers, rather than the effect of QPIP itself. If this were the case however, we might also expect to find comparable results to our main specifications on older mothers' full-time employment, part-time employment and unemployment. That we find no significant effects on these outcomes for older mothers provides some re-assurance as to the validity of our results.

Table 4.8 Robustness Check 3: Alternative treatment groups

\begin{tabular}{|c|c|c|c|c|c|c|c|c|c|c|}
\hline & \multicolumn{2}{|c|}{$\begin{array}{l}\text { Labor force } \\
\text { participation }\end{array}$} & \multicolumn{2}{|c|}{$\begin{array}{l}\text { Full-time } \\
\text { employment }\end{array}$} & \multicolumn{2}{|c|}{$\begin{array}{l}\text { Part-time } \\
\text { employment }\end{array}$} & \multicolumn{2}{|c|}{$\begin{array}{l}\text { Unemploy- } \\
\text { ment }\end{array}$} & \multirow{2}{*}{$\begin{array}{l}\text { (In) } \\
\text { wages } \\
\text { B }\end{array}$} & \multirow{2}{*}{$\begin{array}{l}\text { Hourly } \\
\text { SE B }\end{array}$} \\
\hline & $\mathrm{B}$ & SE B & $\mathrm{B}$ & SE B & $\mathrm{B}$ & SE B & $\mathrm{B}$ & SE B & & \\
\hline \multicolumn{11}{|c|}{ Mothers of older children } \\
\hline Estimator & $0.06 * *$ & 0.01 & 0.03 & 0.02 & -0.01 & 0.02 & -0.02 & 0.01 & 0.03 & 0.02 \\
\hline $\mathrm{R} 2$ & 0.13 & & 0.14 & & 0.12 & & 0.02 & & 0.29 & $\mathrm{R} 2$ \\
\hline $\mathrm{N}$ & 11,131 & & 9,680 & & 9,420 & & 8,927 & & 8,344 & $\mathrm{~N}$ \\
\hline \multicolumn{11}{|c|}{ Fathers of young children } \\
\hline Estimator & -0.01 & 0.02 & -0.03 & 0.02 & 0.04 & 0.02 & -0.03 & 0.02 & 0.03 & 0.02 \\
\hline R2 & 0.17 & & 0.15 & & 0.14 & & 0.03 & & 0.35 & \\
\hline $\mathrm{N}$ & 6,352 & & 5,680 & & 5,542 & & 5,185 & & 4,971 & \\
\hline
\end{tabular}

Note: Models include full year dummies and controls for age, age-squared and number of children, years of education and years of work experience; $* p<0.05$. $* * \mathrm{p}<0.01$.

In a final robustness check, we return to the concern that differential effects of Great Recession on Quebec and Ontario may be driving our results for labor force participation, full-time and part-time employment and unemployment. If, indeed our results were a spurious artifact of the recession, we would expect to find similar results for other groups, with effects concentrated in 2008 and 2009. To analyze whether this is the case we run our Model 3 specification using fathers of young children as our treatment group. As shown in Table 4.9, we find no such effects. We do find that fathers exposed to the policy were nine percentage points less likely to work full-time in 2007, perhaps indicating that the policy may have been successful in reducing gendered household specialization among fathers. However this effect dissipates and becomes statistically nonsignificant in subsequent years. 
Table 4.9 Robustness Check 4: Test for recession effect on fathers of young children

\begin{tabular}{|c|c|c|c|c|c|c|c|c|c|c|c|}
\hline & & \multicolumn{2}{|c|}{$\begin{array}{l}\text { Labor force } \\
\text { participation }\end{array}$} & \multicolumn{2}{|c|}{$\begin{array}{l}\text { Full-time } \\
\text { employment }\end{array}$} & \multicolumn{2}{|c|}{$\begin{array}{l}\text { Part-time } \\
\text { employment }\end{array}$} & \multicolumn{2}{|c|}{$\begin{array}{l}\text { Unemploy- } \\
\text { ment }\end{array}$} & \multirow{2}{*}{$\begin{array}{l}\text { (In) } \\
\text { wages } \\
\text { B } \\
\end{array}$} & \multirow{2}{*}{$\begin{array}{l}\text { Hourly } \\
\text { SE B }\end{array}$} \\
\hline & & B & SE B & $B$ & SE B & $B$ & SE B & B & SE B & & \\
\hline Treat & & 0.02 & 0.02 & 0.03 & 0.02 & -0.03 & 0.02 & 0.01 & 0.02 & $-0.07 * *$ & 0.02 \\
\hline Treat & $x$ & & & & & & & & & & \\
\hline 2007 & & 0.01 & 0.03 & $-0.09 *$ & 0.04 & 0.08 & 0.04 & 0.01 & 0.05 & 0.01 & 0.05 \\
\hline Treat & $x$ & & & & & & & & & & \\
\hline 2008 & & -0.01 & 0.03 & -0.02 & 0.04 & 0.02 & 0.04 & -0.04 & 0.04 & -0.00 & 0.04 \\
\hline Treat & $x$ & & & & & & & & & & \\
\hline 2009 & & -0.02 & 0.03 & -0.02 & 0.04 & 0.03 & 0.04 & -0.04 & 0.03 & 0.04 & 0.03 \\
\hline Treat & $x$ & & & & & & & & & & \\
\hline 2010 & & -0.01 & 0.03 & -0.02 & 0.03 & 0.04 & 0.03 & -0.02 & 0.03 & 0.01 & 0.03 \\
\hline Treat & $x$ & & & & & & & & & & \\
\hline 2011 & & 0.01 & 0.02 & -0.02 & 0.03 & 0.03 & 0.03 & -0.02 & 0.03 & 0.06 & 0.03 \\
\hline $\mathrm{R} 2$ & & 0.17 & & 0.15 & & 0.13 & & 0.03 & & 0.35 & \\
\hline $\mathrm{N}$ & & 6,352 & & 5,680 & & 5,542 & & 5,185 & & 4,971 & \\
\hline
\end{tabular}

Note: Models include full year dummies and controls for age, age-squared and number of children, years of education and years of work experience; $* p<0.05$. $* * \mathrm{p}<0.01$.

In addition to these robustness checks, we run several alternative specifications to test the sensitivity of our results (results are presented in Appendix Tables 3-6). Our main treatment and control groups are comprised of a diverse group of mothers with young children ranging in age from 0-5 years old. Because parental responsibilities and factors like childcare use and availability differ by age of child, QPIP's effect on mothers' labor market outcomes may differ as children grow older. Our data does not allow us to assess the impact of the policy longitudinally, however we use Model 2 to explore the effects of the policy among several subsamples of our treatment and control groups. First, we drop mothers of 5 -year olds from the model as kindergarten is universally available (although not mandatory) in Quebec from age 5. The results, presented in Appendix Table 3, vary little from our main Model 2 findings although the coefficient on hourly wages is slightly larger at 0.06 and statistically significant where it was 0.04 and non-significant in our main specifications.

Next, we run model two for a sample of mothers of 1-2 year olds throughout the period of analysis and then for mothers of 3-4 year olds. As shown in Appendix Table 4 - 5, our results are qualitatively similar to our main findings. For mothers of 1-2 year olds, the magnitudes of effects are broadly similar but standard errors are larger in several instances, reflecting the substantially reduced sample size. For mothers of 3-4 year olds, the magnitudes of effects are smaller than our main results and nonsignificant however it is important to note that the post period in this specification can only be drawn from 2010 and 2011 and therefore post year sample sizes are small. That said, the direction of effects for this group are in line with our expectations and main results. 
Finally, we run our Model 2 specifications on a sample of treated and control group mothers of children age 0-5 years old in each year of analysis as opposed to our main specifications in which the sample definition changes by age of youngest child in each post year. Results are largely consistent with our main findings although the magnitude of coefficients is smaller for some outcomes than in our main specifications. This is unsurprising, however, considering that in post years our treatment group is "diluted" with Quebec mothers who's children were born prior to 2006 and were therefore not eligible for the policy.

\section{Discussion \& Conclusion}

The results of our analysis suggest that the introduction of QPIP has improved some of mothers' labor market outcomes in the province, with Quebec mothers exposed to the policy more likely to participate in the labor force than they would have been in the absence of the policy. Further investigation shows that much of this increased labor force participation manifests as full-time work and that mothers exposed to the policy are less likely work part-time and less likely to be unemployed. Finally, although these findings are in line with our hypothesis that a daddy quota such as QPIP may reduce mothers' specialization at the household level, allowing them to dedicate more time and effort to paid work, we do not find evidence that the policy had a statistically significant effect on mothers' hourly wages. These results are robust to a variety of battery of placebo and sensitivity tests including an alternative non-parametric matching technique a year placebo test, and a variety of robustness checks using placebo treatment groups.

The null result on mothers' hourly wages could be interpreted in a number of ways. First, it is possible that QPIP simply had no discernable impact on mothers' wages. It is also possible that it may take several years to observe substantial increases in earnings associated with increased participation in the labor force, and that our period of analysis is too short to capture such effects. Alternatively, the result could indicate that although QPIP's increases mothers' labor market activities, it does not diminish the competency bias they face in the work place (e.g. Correll, Benard, \& Paik, 2007) and therefore does not result in higher wages. The repeated crosssectional nature of our data substantially limits our ability to explore these possibilities further. Future research would benefit from longitudinal analysis of wage trajectories, which could better reflect how mothers' wages develop longitudinally as a result of QPIP.

Our results broken down by year find that QPIP's effects are concentrated in 2008 and 2009, decreasing in size and significance in 2010 and 2011. That the dissipation of QPIP's effects took place in the immediate wake of 
the Canada's Great Recession in 2009 raises questions over the efficacy of such policies in times of economic uncertainty. Alternatively, the decrease in size and statistical significance of QPI P's effects on mothers' labor market outcomes could indicate that the effects of the policy are exclusively shortterm and have no lasting impact on mothers' career outcomes in the medium run. In an effort to explore this possibility, we conducted an exploratory triple difference model analysing QPIP's effects on Quebec mothers, broken down by age of child however small cell counts and a lack of precision made it difficult to draw a clear conclusion about how the policies effects differ across the age of the child.

As suggested above, future research could shed light on this question by analysing mothers' outcomes longitudinally and over a longer period of time, which was not possible in this analysis due to sample size constraints of SLID's panel component and the survey's discontinuation in 2011. Such analysis would provide valuable insight into when and how QPIP's impact on mothers' labor market outcomes manifest and how they develop in the longer term as children grow older.

This research contributes to the broader literature on work-family reconciliation policies by assessing the effects of the implementation of a daddy quota in a non-Nordic setting and adds to a growing body of empirical evaluations of such policy instruments. Given the motherhood penalty's role in driving persisting gender equalities such as the gender wage gap and the increasing prominence of daddy quotas in policy debates across industrialized countries, gaining a better understanding of the effect of daddy quotas as a potential policy tool for addressing economic gender inequalities in a variety of contexts is critical.

Our results should be considered alongside the findings of previous research. Our estimates show that QPIP increases mothers' labor force participation and full-time employment and decreases their part-time employment and unemployment, in line with Patnaik's (forthcoming) findings that the policy increased mothers' time spent in paid work. However, these findings are at odds with the null and negative effects on mothers' labor supply in Norway identified by Ekberg et al. (2013) and by Cools et al. (2015), respectively. On the other hand, our non-significant results regarding QPIP's affect on mothers' wages appears to contrast both Johansson's (2010) and Andersen's (2018) positive estimates and Cools et al.'s (2015) negative one.

The results from this analysis provide important evidence that daddy quotas may be useful policy tools for addressing gender inequalities in the labor market, however, as discussed above, further research in this area is warranted. As more than a decade has now passed since the implementation of the policy, future studies would do well to investigate longer-term effects of the reform. Future investigations would also benefit 
from considering additional labor market outcomes unavailable in SLID like job promotions or female entrepreneurship. Finally, further research on QPIP and daddy quotas in other contexts is required to gain an understanding of how such policies operate under varying macroeconomic conditions, particularly during and outside recessions and other such global shocks.

\section{References}

Andersen, S. H. (2018). Paternity Leave and the Motherhood Penalty: New Causal Evidence, 80(October), 1125-1143. https://doi.org/10.1111/jomf. 12507

Becker, G. S. (1985). Human-Capital, Effort, and the Sexual Division of Labor. J Labor Econ, 3(1), S33-S58. https://doi.org/Doi $10.1086 / 298075$

Bianchi, S. M. (2011). Family Change and Time Allocation in American Families. Annals of the American Academy of Political and Social Science, 638(1), 21-44. https://doi.org/http://dx.doi.org/10.1177/0002716211413731

Bianchi, S. M., Sayer, L. C., Milkie, M. A., \& Robinson, J. P. (2012). Housework: Who did, does or will do it, and how much does it matter? Social Forces, 91(1), 55-63. https://doi.org/10.1093/sf/sos120

Bjornberg, U. (2002). I deology and choice between work and care: Swedish family policy for working parents. Critical Social Policy, 22(1), 33-52. https://doi.org/10.1177/02610183020220010401

Brandth, B., \& Kvande, E. (1998). Masculinity and Child Care: The Reconstruction of Fathering. The Sociological Review, 46(2), 293313. https://doi.org/10.1111/1467-954X.00120

Budig, M. (2014). The Fatherhood Bonus and The Motherhood Penalty: Parenthood and the Gender Gap in Pay - Third Way. Washington, D.C. Retrieved from http://www.thirdway.org/report/the-fatherhoodbonus-and-the-motherhood-penalty-parenthood-and-the-gendergap-in-pay

Budig, M., Misra, J., \& Boeckmann, I. (2012). The Motherhood Penalty in Cross-National Perspective: The Importance of Work-Family Policies and Cultural Attitudes. Social Politics, 19(2), 163-193. Retrieved from http: //dx. doi.org/10.1093/sp/jxs006

Buligescu, B., de Crombrugghe, D., Menteşoğlu, G., \& Montizaan, R. (2009). Panel estimates of the wage penalty for maternal leave. Oxford Economic Papers, 61(SPEC. ISS.). https://doi.org/10.1093/oep/gpn042 
Bünning, M. (2015). What happens after the "Daddy Months"? Fathers' involvement in paid work, childcare, and housework after taking parental leave in Germany. European Sociological Review, 31(6). https://doi.org/10.1093/esr/jcv072

Bygren, M., \& Duvander, A. Z. (2006). Parents' workplace situation and fathers' parental leave use. Journal of Marriage and Family, 68(2), 363-372. https://doi.org/10.1111/j.1741-3737.2006.00258.x

Cools, S., Fiva, J. H., \& Kirkeboen, L. J. (2015). Causal Effects of Paternity Leave on Children and Parents. Scandinavian Journal of Economics, 117(3), 801-828. https://doi.org/10.1111/sjoe.12113

Correl, S. J., Benard, S., \& Paik, I. (2007). Getting a Job: Is There a Motherhood Penalty? American Journal of Sociology, 112(5), 12971338. https: // doi.org/10.1086/511799

Crittenden, A. (2002). The Price of Motherhood: Why the Most Important Job in the World is Still the Least Valued. https://doi.org/10.1177/0886109902173010

Ekberg, J., Eriksson, R., \& Friebel, G. (2013). Parental leave - A policy evaluation of the Swedish "Daddy-Month" reform. Journal of Public Economics, 97(1). https://doi.org/10.1016/j.jpubeco.2012.09.001

Farré, L., \& González, L. (2019). Does paternity leave reduce fertility? 次. Journal of Public Economics, 172, 52-66. https://doi.org/10.1016/j.jpubeco.2018.12.002

Fortin, P., Godbout, L., \& St-Cerny, S. (2012). Impact of Quebec's Universal Low Fee Childcare Program on Female Labour Force Participants, domestic Income, and Government Budgets (No. 2012/02). Chaire de recherche en fiscalite et finances publiques.

Fox, E., Pascall, G., \& Warren, T. (2009). Work-family policies, participation, and practices: fathers and childcare in Europe. Community, Work \& Family, 12(3), 313-326. https://doi.org/10.1080/13668800902966323

Geisler, E., \& Kreyenfeld, M. (2012). How Policy Matters: Germany's Parental Leave Benefit Reform and Fathers' Behavior 1999-2009 (Vol. 21).

Haas, L., \& Hwang, C. P. (2008). The Impact of Taking Parental Leave on Fathers' Participation in Childcare and Relationships with Children: Lessons from Sweden. Community, Work \& Family, 11(1), 85-104. https://doi.org/10.1080/13668800701785346

Haas, L., \& Rostgaard, T. (2011). Fathers' rights to paid parental leave in the Nordic countries: consequences for the gendered division of leave. Community, Work \& Family, 14(2), 177-195. https: // doi.org/10.1080/13668803.2011.571398 
Harkness, S., \& Waldfogel, J. (2003). the Family Gap in Pay: Evidence From Seven Industrialized Countries. Research in Labor Economics, 22, 369-413. https://doi.org/10.1016/S0147-9121(03)22012-4

Hook, J. L. (2006). Care in Context: Men's Unpaid Work in 20 Countries 1965-2003. American Sociological Review, 71, 639-660.

Hook, J. L. (2010). Gender Inequality in the Welfare State: Sex Segregation in Housework, 1965-2003. American Journal of Sociology, 115(5), 1480-1523. https://doi.org/10.1086/651384

Johansson, E.-A. (2010). The effect of own and spousal parental leave on earnings. IFAU - Institute for Labour Market Policy Evaluation Working Paper, 4, 1- 32.

Johansson, E. (2010). The effect of own and spousal parental leave on earnings. IFAU - Institute for Labour Market Policy Evaluation Working Paper, 4.

Kluve, J., \& Schmitz, S. (2014). Social Norms and Mothers' Labor Market Attachment

(No.

481).

https://doi.org/http://dx.doi.org/10.4419/86788545

Kotsadam, A., \& Finseraas, H. (2011). The state intervenes in the battle of the sexes: Causal effects of paternity leave. Social Science Research, 40(6),

1611- 1622.

https://doi.org/10.1016/j.ssresearch.2011.06.011

Lammi-Taskula, J. (2006). Nordic men on parental leave: can the welfare state change gender relations. Politicising Parenthood in Scandinavia: Gender Relations in Welfare States, 79-99. Retrieved from http://goo.gl/5Sdkgm

Manning, A., \& Petrongolo, B. (2008). The part-time pay penalty for women in britain. Economic Journal, 118(526). https://doi.org/10.1111/j.1468-0297.2007.02115.x

Morgan, K. J., \& Zippel, K. (2003). Paid to Care: The Origins and Effects of Care Leave Policies in Western Europe. Social Politics, 10(1). https://doi.org/10.1093/sp/jxg004

Morgenroth, T., \& Heilman, M. E. (2017). Journal of Experimental Social Psychology Should I stay or should I go? Implications of maternity leave choice for perceptions of working mothers is. Journal of Experimental Social Psychology, 72(May), 53-56. https://doi.org/10.1016/j.jesp.2017.04.008

Moyser, M., \& Milan, A. (2018). Insights on Canadian Society Fertility rates and labour force participation among women in Quebec and Ontario.

Nepomnyaschy, L., \& Waldfogel, J. (2007). Paternity leave and fathers' involvement with their young children: Evidence from the American ECLS-B. Community, Work \& Family, 10(4), 427-453. https://doi.org/http://dx.doi.org/10.1080/13668800701575077 
OECD. (2012). Closing the Gender Gap: Act Now. OECD Publishing, 352. https://doi.org/10.1787/9789264179370-en

Patnaik, A. (n.d.). Reserving Time for Daddy: The Consequences of Fathers' Quotas. Journal of Labor Economics.

Pettit, B., \& Hook, J. L. (2009). Gendered Tradeoffs: Family, Social Policy and Eocnomic Inequality in Twenty-one countries. New York: Russell Sage Foundation.

Service Canada. (2016). Digest of Benefit Entitlement Principles Chapter 12 - Maternity benefits. Retrieved March 25, 2017, from goo.gl/6FSVH1

Sigle-Rushton, W., \& Waldfogel, J. (2007). Motherhood and women's earnings in Anglo-American, Continental European, and Nordic Countries. Feminist Economics, 13(2), 55-91. https://doi.org/10.1080/13545700601184849

Statistics Canada. (2017). CANSIM table 282-0002. Retrieved March 25, 2017, from goo.gl/KNsYzY

Sullivan, O., Coltrane, S., Mcannally, L., \& Altintas, E. (2009). FatherFriendly Policies and Time-Use Data in a Cross-National Context: Potential and Prospects for Future Research. The ANNALS of the American Academy of Political and Social Science, 624(J uly 2009), 234-254. https://doi.org/10.1177/0002716209335138

Tanaka, S., \& Waldfogel, J. (2007). Effects of parental leave and working hours on fathers' involvement with their babies: Evidence from the UK Millennium Cohort Study. Community, Work \& Family, 10(4), 409- 426.

Waldfogel, J. (1998). Understanding the "Family Gap" in Pay for Women with Children. Journal of Economic Perspectives, 12(1), 137-156. https://doi.org/10.1257/jep.12.1.137

Zhelyazkova, N. (2013). Fathers' use of parental leave. What do we know? (MERIT working papers No. 22). 


\section{Appendix}

\section{Labor Market Outcome Variables of I nterest}

We define our outcome variables of interest using several SLID survey indicators:

1. Labor force participation, equal to ' 1 ' if the respondent is in the labor force during the reference year and ' 0 ' otherwise.

2. Full-time employment status, conditional on being in the labor force, equal to ' 1 ' if the respondent is employed full-time during the given reference year, and ' 0 ' if unemployed or employed part-time. Respondents who are out of the labor force during the reference year are coded as missing.

3. Part-time employment status, equal to ' 1 ' if the respondent is employed less than full-time during the given reference year. This includes individuals who were employed part of the year as well as those employed part-time all year round. This indicator is equal to ' 0 ' where the individual is employed full-time during the reference year. Respondents who are out of the labor force during the reference year are coded as missing.

4. Unemployment, equal to ' 1 ' if the respondent is unemployed at any point during the reference year and ' 0 ' if the respondent is employed the entirety of the reference year. Respondents who are out of the labor force during the reference year are coded as missing.

5. Log hourly wage, based on a continuous variable reporting hourly wages for all respondents with earnings during the reference year, expressed in constant 2002 Canadian Dollars (rebased using Statistics Canada's annual consumer price index). This indicator uses SLID's measure of pre-tax, pre-transfer earnings, recorded directly for respondents who report their earnings as an hourly amount, or converted to an hourly rate for individuals who report other wage formats using other information provided. 


\section{Appendix Table 1 Labor Market Outcomes over time for Treatment and Control Groups}

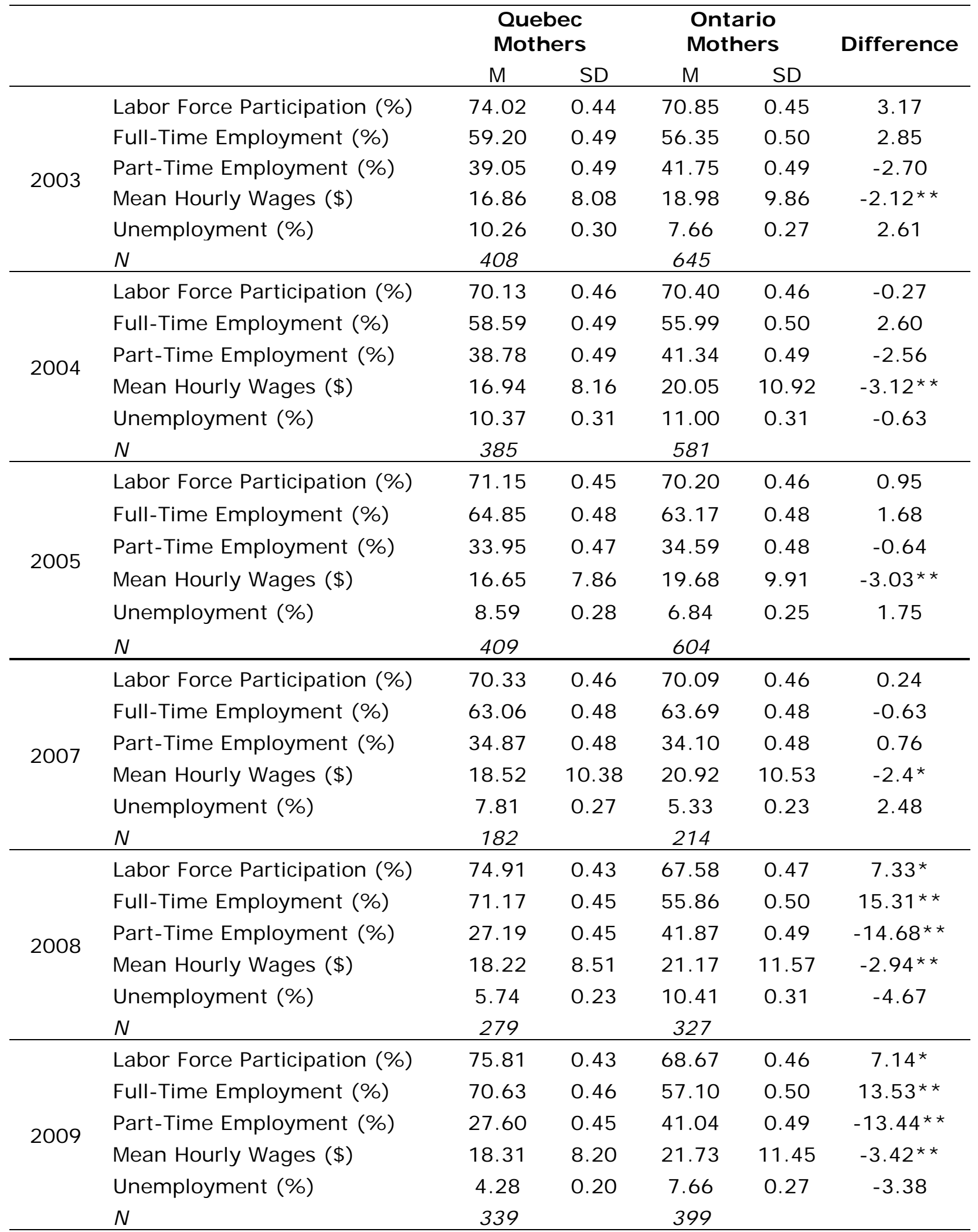




\begin{tabular}{|c|c|c|c|c|c|c|}
\hline & & \multicolumn{2}{|c|}{$\begin{array}{l}\text { Quebec } \\
\text { Mothers }\end{array}$} & \multicolumn{2}{|c|}{$\begin{array}{l}\text { Ontario } \\
\text { Mothers }\end{array}$} & \multirow[t]{2}{*}{ Difference } \\
\hline & & M & SD & M & SD & \\
\hline \multirow{6}{*}{2010} & Labor Force Participation (\%) & 79.18 & 0.41 & 72.45 & 0.45 & $6.72 *$ \\
\hline & Full-Time Employment (\%) & 64.72 & 0.48 & 61.82 & 0.49 & 2.90 \\
\hline & Part-Time Employment (\%) & 33.65 & 0.47 & 35.61 & 0.48 & -1.96 \\
\hline & Mean Hourly Wages (\$) & 19.43 & 9.83 & 21.99 & 11.71 & $-2.57 * *$ \\
\hline & Unemployment (\%) & 7.96 & 0.27 & 10.54 & 0.31 & -2.58 \\
\hline & $\mathrm{N}$ & 365 & & 432 & & \\
\hline \multirow{6}{*}{2011} & Labor Force Participation (\%) & 76.96 & 0.42 & 73.46 & 0.44 & 3.51 \\
\hline & Full-Time Employment (\%) & 67.73 & 0.47 & 66.33 & 0.47 & 1.40 \\
\hline & Part-Time Employment (\%) & 29.82 & 0.46 & 30.87 & 0.46 & -1.05 \\
\hline & Mean Hourly Wages (\$) & 19.33 & 8.59 & 21.35 & 9.47 & $-2.02 * *$ \\
\hline & Unemployment (\%) & 4.28 & 0.20 & 6.44 & 0.25 & -2.17 \\
\hline & $\mathrm{N}$ & 395 & & 486 & & \\
\hline
\end{tabular}

Notes: Hourly wages are shown in 2002 Canadian dollars; Asterisks indicate where group differences are statistically significant using a two-tailed t-test; $* \mathrm{p}<0.05$ ** $\mathrm{p}<0.01$ 


\section{Appendix Table 2 Composition Treatment and Control Groups over}

time

\begin{tabular}{|c|c|c|c|c|c|c|}
\hline & & \multicolumn{2}{|c|}{$\begin{array}{l}\text { Quebec } \\
\text { Mothers }\end{array}$} & \multicolumn{2}{|c|}{$\begin{array}{l}\text { Ontario } \\
\text { Mothers }\end{array}$} & \multirow[t]{2}{*}{ Difference } \\
\hline & & M & SD & $M$ & SD & \\
\hline \multirow{4}{*}{2003} & $\begin{array}{l}\text { Years of education } \\
\text { Years of work }\end{array}$ & 14.31 & 3.17 & 14.73 & 2.81 & $-0.42 *$ \\
\hline & experience & 8.00 & 5.90 & 8.41 & 6.10 & -0.41 \\
\hline & Average Age & 31.56 & 5.53 & 33.00 & 5.62 & $-1.44 * *$ \\
\hline & Number of children & 1.93 & 0.91 & 2.01 & 0.93 & -0.07 \\
\hline \multirow{4}{*}{2004} & $\begin{array}{l}\text { Years of education } \\
\text { Years of work }\end{array}$ & 14.47 & 3.22 & 14.95 & 2.88 & $-0.48^{*}$ \\
\hline & experience & 7.90 & 5.90 & 8.56 & 5.89 & -0.66 \\
\hline & Average Age & 31.60 & 5.48 & 33.19 & 5.53 & $-1.59 * *$ \\
\hline & Number of children & 1.93 & 0.91 & 1.98 & 0.89 & -0.05 \\
\hline \multirow{4}{*}{2005} & $\begin{array}{l}\text { Years of education } \\
\text { Years of work }\end{array}$ & 14.14 & 2.71 & 14.62 & 2.67 & $-0.48 * *$ \\
\hline & experience & 8.29 & 5.60 & 8.34 & 6.13 & -0.05 \\
\hline & Average Age & 32.09 & 5.51 & 33.46 & 5.45 & $-1.37 * *$ \\
\hline & Number of children & 1.89 & 0.88 & 2.01 & 0.90 & $-0.12 *$ \\
\hline \multirow{4}{*}{2007} & $\begin{array}{l}\text { Years of education } \\
\text { Years of work }\end{array}$ & 14.59 & 2.60 & 15.02 & 2.86 & -0.43 \\
\hline & experience & 6.87 & 4.74 & 7.78 & 5.27 & -0.91 \\
\hline & Average Age & 29.85 & 4.63 & 31.88 & 5.01 & $-2.03 * *$ \\
\hline & Number of children & 1.74 & 0.87 & 1.91 & 0.90 & -0.17 \\
\hline \multirow{4}{*}{2008} & $\begin{array}{l}\text { Years of education } \\
\text { Years of work }\end{array}$ & 14.08 & 2.54 & 14.73 & 2.63 & $-0.65^{* *}$ \\
\hline & experience & 6.89 & 4.89 & 7.57 & 5.33 & -0.68 \\
\hline & Average Age & 30.75 & 4.99 & 31.88 & 5.18 & $-1.13 * *$ \\
\hline & Number of children & 1.79 & 0.82 & 1.91 & 0.87 & -0.12 \\
\hline \multirow{4}{*}{2009} & $\begin{array}{l}\text { Years of education } \\
\text { Years of work }\end{array}$ & 14.25 & 2.58 & 14.93 & 2.58 & $-0.68 * *$ \\
\hline & experience & 7.22 & 5.00 & 7.87 & 5.49 & -0.65 \\
\hline & Average Age & 31.39 & 5.33 & 32.48 & 5.27 & $-1.09 * *$ \\
\hline & Number of children & 1.82 & 0.04 & 1.98 & 0.93 & $-0.16 *$ \\
\hline \multirow{4}{*}{2010} & $\begin{array}{l}\text { Years of education } \\
\text { Years of work }\end{array}$ & 14.26 & 2.64 & 14.82 & 2.64 & $-0.56 * *$ \\
\hline & experience & 8.18 & 5.21 & 8.42 & 5.68 & -0.24 \\
\hline & Average Age & 32.05 & 5.44 & 33.10 & 5.36 & $-1.05^{* *}$ \\
\hline & Number of children & 1.85 & 0.84 & 1.97 & 0.87 & -0.11 \\
\hline \multirow{4}{*}{2011} & $\begin{array}{l}\text { Years of education } \\
\text { Years of work }\end{array}$ & 14.27 & 2.72 & 15.19 & 2.63 & $-0.92 * *$ \\
\hline & experience & 8.81 & 5.47 & 8.41 & 5.68 & 0.4 \\
\hline & Average Age & 32.76 & 5.28 & 33.67 & 5.29 & $-0.92 *$ \\
\hline & Number of children & 1.95 & 0.88 & 2.01 & 0.92 & -0.06 \\
\hline
\end{tabular}

Notes: Hourly wages are shown in 2002 Canadian dollars; Asterisks indicate where group differences are statistically significant using a two-tailed t-test; $* \mathrm{p}<0.05$ $* * \mathrm{p}<0.01$ 
Appendix Table 3 I mpact of QPI P on Mothers' Labor Market Outcomes, Model2, mothers of 0-4 year olds

\begin{tabular}{lcccccccccc}
\hline & $\begin{array}{c}\text { Labor force } \\
\text { participation }\end{array}$ & \multicolumn{2}{c}{$\begin{array}{c}\text { Full-time } \\
\text { employment }\end{array}$} & \multicolumn{2}{c}{$\begin{array}{c}\text { Part-time } \\
\text { employment }\end{array}$} & \multicolumn{2}{c}{$\begin{array}{c}\text { (In) Hourly } \\
\text { wages }\end{array}$} & \multicolumn{2}{c}{$\begin{array}{c}\text { Unemploymen } \\
\text { t }\end{array}$} \\
\cline { 2 - 12 } & B & SE B & B & SE B & B & SE B & B & SE B & B & SE B \\
\hline $\begin{array}{l}\text { Treat } x \\
\text { Post }\end{array}$ & $0.06^{*}$ & 0.02 & $0.06^{*}$ & 0.03 & $0.06^{*}$ & 0.03 & $0.06^{*}$ & 0.02 & $0.05^{* *}$ & 0.02 \\
& & & & & & & - & & & \\
Treat & 0.01 & 0.02 & 0.03 & 0.02 & -0.03 & 0.02 & $0.07 * *$ & 0.02 & 0.01 & 0.01 \\
Post & 0.00 & 0.02 & 0.04 & 0.03 & -0.04 & 0.03 & $0.06 *$ & 0.03 & -0.00 & 0.02 \\
N & 5951 & & 4910 & & 4746 & & 4330 & & 4297 & \\
\hline
\end{tabular}

Note: Models 2 include full year dummies and controls for age, age-squared, number of children, years of education and years work experience; $* p<0.05$ $* * \mathrm{p}<0.01$.

\section{Appendix Table 4 I mpact of QPI P on Mothers' Labor Market Outcomes, Model2, mothers of 1-2 year olds}

\begin{tabular}{lcccccccccc}
\hline & $\begin{array}{c}\text { Labor force } \\
\text { participation }\end{array}$ & \multicolumn{2}{c}{$\begin{array}{c}\text { Full-time } \\
\text { employment }\end{array}$} & \multicolumn{2}{c}{$\begin{array}{c}\text { Part-time } \\
\text { employment }\end{array}$} & \multicolumn{2}{c}{$\begin{array}{c}\text { (In) Hourly } \\
\text { wages }\end{array}$} & \multicolumn{2}{c}{ Unemployment } \\
\cline { 2 - 11 } & B & SE B & B & SE B & B & SE B & B & SE B & B & SE B \\
\hline $\begin{array}{l}\text { Treat } x \\
\text { Post }\end{array}$ & $0.06^{*}$ & 0.03 & 0.06 & 0.04 & -0.05 & 0.04 & $0.07^{*}$ & 0.03 & $0.08^{* *}$ & 0.03 \\
& & & & & & & - & & & \\
Treat & 0.03 & 0.02 & 0.05 & 0.02 & -0.04 & 0.03 & $0.08^{* *}$ & 0.02 & 0.02 & 0.02 \\
Post & -0.03 & 0.03 & -0.00 & 0.04 & 0.03 & 0.04 & 0.03 & 0.04 & $0.07^{*}$ & 0.03 \\
N & 3330 & & 2703 & & 2614 & & 2391 & & 2348 & \\
\hline
\end{tabular}

Note: Models 2 include full year dummies and controls for age, age-squared, number of children, years of education and years work experience; $* \mathrm{p}<0.05$ $* * \mathrm{p}<0.01$.

\section{Appendix Table 5 I mpact of QPI P on Mothers' Labor Market Outcomes, Model2, mothers of 3-4 year olds}

\begin{tabular}{|c|c|c|c|c|c|c|c|c|c|c|}
\hline & \multicolumn{2}{|c|}{$\begin{array}{l}\text { Labor force } \\
\text { participation }\end{array}$} & \multicolumn{2}{|c|}{$\begin{array}{c}\text { Full-time } \\
\text { employment }\end{array}$} & \multicolumn{2}{|c|}{$\begin{array}{c}\text { Part-time } \\
\text { employment }\end{array}$} & \multicolumn{2}{|c|}{$\begin{array}{c}\text { (In) Hourly } \\
\text { wages }\end{array}$} & \multicolumn{2}{|c|}{ Unemployment } \\
\hline & B & SE B & B & SE B & B & $\begin{array}{c}\text { SE } \\
\text { B }\end{array}$ & B & SE B & B & SE B \\
\hline $\begin{array}{l}\text { Treat } x \\
\text { Post }\end{array}$ & 0.03 & 0.04 & 0.03 & 0.05 & -0.01 & 0.05 & 0.07 & 0.05 & -0.05 & 0.03 \\
\hline Treat & 0.02 & 0.02 & $0.05^{*}$ & 0.02 & -0.05 & 0.02 & $-0.06 * *$ & 0.02 & -0.00 & 0.02 \\
\hline Post & -0.04 & 0.04 & 0.01 & 0.05 & 0.05 & 0.05 & 0.07 & 0.05 & 0.00 & 0.03 \\
\hline $\mathrm{N}$ & 2372 & & 1991 & & 1922 & & 1703 & & 1792 & \\
\hline
\end{tabular}

Note: Models 2 include full year dummies and controls for age, age-squared, number of children, years of education and years work experience; $* p<0.05$ $* * \mathrm{p}<0.01$. 


\section{Appendix Table 6 I mpact of QPI P on Mothers' Labor Market Outcomes, Model2, mothers of 0-5 year olds (consistent sample definition in each year)}

\begin{tabular}{lcccccccccc}
\hline & \multicolumn{2}{c}{$\begin{array}{c}\text { Labor force } \\
\text { participation }\end{array}$} & \multicolumn{2}{c}{$\begin{array}{c}\text { Full-time } \\
\text { employment }\end{array}$} & \multicolumn{2}{c}{$\begin{array}{c}\text { Part-time } \\
\text { employment }\end{array}$} & \multicolumn{2}{c}{$\begin{array}{c}\text { (In) Hourly } \\
\text { wages }\end{array}$} & \multicolumn{2}{c}{ Unemployment } \\
\cline { 2 - 11 } & B & SE B & B & SE B & B & SE B & B & SE B & B & SE B \\
\hline Treat $x$ & & & & & - & & & & & \\
Post & $0.04 *$ & 0.02 & $0.05^{*}$ & 0.02 & $0.05^{*}$ & 0.02 & $0.05^{*}$ & 0.02 & -0.03 & 0.02 \\
Treat & 0.02 & 0.02 & 0.03 & 0.02 & -0.03 & 0.02 & $-0.06^{* *}$ & 0.02 & 0.01 & 0.01 \\
& & & - & & & & & & - & \\
Post & 0.02 & 0.02 & $0.05^{*}$ & 0.03 & 0.05 & 0.03 & $0.07^{* *}$ & 0.02 & $0.04 *$ & 0.02 \\
N & 7694 & & 6343 & & 6122 & & 5534 & & & 5588 \\
\hline
\end{tabular}

Note: Models 2 include full year dummies and controls for age, age-squared, number of children, years of education and years work experience; $* p<0.05$ $* * \mathrm{p}<0.01$.

Appendix Table 7 I mpact of QPI P on Mothers' Labor Force Participation, variations on Models 2 and 3

\begin{tabular}{|c|c|c|c|c|c|c|c|c|}
\hline & \multicolumn{2}{|c|}{$\begin{array}{l}\text { Model } 2 \text { without } \\
\text { number of } \\
\text { children }\end{array}$} & \multicolumn{2}{|c|}{$\begin{array}{l}\text { Model } 3 \text { without } \\
\text { number of } \\
\text { children }\end{array}$} & \multicolumn{2}{|c|}{$\begin{array}{l}\text { Model } 2 \text { without } \\
\text { education or } \\
\text { work experience }\end{array}$} & \multicolumn{2}{|c|}{$\begin{array}{l}\text { Model } 2 \text { without } \\
\text { education or } \\
\text { work experience }\end{array}$} \\
\hline & B & SE B & B & SE B & B & SE B & B & SE B \\
\hline Treat x Post & $0.05^{*}$ & 0.02 & & & 0.03 & 0.02 & & \\
\hline Treat & 0.02 & 0.02 & 0.02 & 0.02 & 0.02 & 0.02 & 0.02 & 0.02 \\
\hline Post & -0.04 & 0.03 & & & -0.01 & 0.03 & & \\
\hline Treat x 2007 & & & -0.00 & 0.05 & & & -0.01 & 0.05 \\
\hline Treat x 2008 & & & $0.08^{*}$ & 0.04 & & & 0.05 & 0.04 \\
\hline Treat x 2009 & & & $0.08 *$ & 0.03 & & & 0.05 & 0.04 \\
\hline Treat x 2010 & & & 0.06 & 0.03 & & & 0.05 & 0.03 \\
\hline Treat x 2011 & & & 0.02 & 0.03 & & & 0.02 & 0.03 \\
\hline R2 & 0.15 & & 0.15 & & 0.06 & & 0.06 & \\
\hline $\mathrm{N}$ & 6,450 & & 6,450 & & 6,450 & & 6,450 & \\
\hline
\end{tabular}

Note: Models 2 and 3 include full year dummies and controls for age, age-squared, number of children, years of education and years work experience; * $\mathrm{p}<0.05 * *$ $\mathrm{p}<0.01$. 


\section{Appendix Table 8 I mpact of QPIP on Mothers' Full-time employment, variations on Models 2 and 3}

\begin{tabular}{|c|c|c|c|c|c|c|c|c|}
\hline & \multicolumn{2}{|c|}{$\begin{array}{l}\text { Model } 2 \text { without } \\
\text { number of } \\
\text { children }\end{array}$} & \multicolumn{2}{|c|}{$\begin{array}{c}\text { Model } 3 \text { without } \\
\text { number of } \\
\text { children }\end{array}$} & \multicolumn{2}{|c|}{$\begin{array}{l}\text { Model } 2 \text { without } \\
\text { education or } \\
\text { work experience }\end{array}$} & \multicolumn{2}{|c|}{$\begin{array}{l}\text { Model } 2 \text { without } \\
\text { education or } \\
\text { work experience }\end{array}$} \\
\hline & $B$ & SE B & $B$ & SE B & $B$ & SE B & $B$ & SE B \\
\hline Treat $\times$ Post & $0.06 *$ & 0.03 & & & 0.04 & 0.03 & & \\
\hline Treat & 0.03 & 0.02 & 0.03 & 0.02 & 0.04 & 0.02 & 0.04 & 0.02 \\
\hline Post & 0.06 & 0.03 & & & 0.04 & 0.03 & & \\
\hline Treat x 2007 & & & -0.01 & 0.05 & & & -0.02 & 0.06 \\
\hline Treat $\times 2008$ & & & $0.15^{* *}$ & 0.05 & & & $0.13 * *$ & 0.05 \\
\hline Treat x 2009 & & & $0.14 * *$ & 0.04 & & & $0.11 * *$ & 0.04 \\
\hline Treat $\times 2010$ & & & 0.02 & 0.04 & & & 0.00 & 0.04 \\
\hline Treat x 2011 & & & -0.01 & 0.04 & & & -0.02 & 0.04 \\
\hline $\mathrm{R} 2$ & 0.12 & & 0.12 & & 0.04 & & 0.04 & \\
\hline $\mathrm{N}$ & 5,308 & & 5,308 & & 5,308 & & 5,308 & \\
\hline
\end{tabular}

Note: Models 2 and 3 include full year dummies and controls for age, age-squared, number of children, years of education and years work experience; * $\mathrm{p}<0.05 * *$ $\mathrm{p}<0.01$.

\section{Appendix Table 9 I mpact of QPI P on Mothers' Part-time employment, variations on Models 2 and 3}

\begin{tabular}{|c|c|c|c|c|c|c|c|c|}
\hline & \multicolumn{2}{|c|}{$\begin{array}{l}\text { Model } 2 \text { without } \\
\text { number of } \\
\text { children }\end{array}$} & \multicolumn{2}{|c|}{$\begin{array}{c}\text { Model } 3 \text { without } \\
\text { number of } \\
\text { children }\end{array}$} & \multicolumn{2}{|c|}{$\begin{array}{l}\text { Model } 2 \text { without } \\
\text { education or } \\
\text { work experience }\end{array}$} & \multicolumn{2}{|c|}{$\begin{array}{l}\text { Model } 2 \text { without } \\
\text { education or } \\
\text { work experience }\end{array}$} \\
\hline & B & SE B & B & SE B & B & SE B & B & SE B \\
\hline Treat $\times$ Post & $-0.06 *$ & 0.03 & & & -0.04 & 0.03 & & \\
\hline Treat & -0.03 & 0.02 & -0.03 & 0.02 & -0.03 & 0.02 & -0.03 & 0.02 \\
\hline Post & -0.05 & 0.03 & & & -0.04 & 0.03 & & \\
\hline Treat x 2007 & & & 0.01 & 0.05 & & & 0.02 & 0.06 \\
\hline Treat $\times 2008$ & & & $0.15^{* *}$ & 0.05 & & & $0.12 * *$ & 0.05 \\
\hline Treat x 2009 & & & $0.14 * *$ & 0.04 & & & $0.12 * *$ & 0.04 \\
\hline Treat $\times 2010$ & & & -0.02 & 0.04 & & & 0.00 & 0.04 \\
\hline Treat x 2011 & & & 0.01 & 0.04 & & & 0.01 & 0.04 \\
\hline $\mathrm{R} 2$ & 0.10 & & 0.11 & & 0.04 & & 0.04 & \\
\hline $\mathrm{N}$ & 5,130 & & 5,130 & & 5,130 & & 5,130 & \\
\hline
\end{tabular}

Note: Models 2 and 3 include full year dummies and controls for age, age-squared, number of children, years of education and years work experience; $* \mathrm{p}<0.05 * *$ $\mathrm{p}<0.01$. 


\section{Appendix Table 10 I mpact of QPI P on Mothers' Unemployment, variations on Models 2 and 3}

\begin{tabular}{|c|c|c|c|c|c|c|c|c|}
\hline & \multicolumn{2}{|c|}{$\begin{array}{l}\text { Model } 2 \text { without } \\
\text { number of } \\
\text { children }\end{array}$} & \multicolumn{2}{|c|}{$\begin{array}{l}\text { Model } 3 \text { without } \\
\text { number of } \\
\text { children }\end{array}$} & \multicolumn{2}{|c|}{$\begin{array}{l}\text { Model } 2 \text { without } \\
\text { education or } \\
\text { work experience }\end{array}$} & \multicolumn{2}{|c|}{$\begin{array}{l}\text { Model } 2 \text { without } \\
\text { education or } \\
\text { work experience }\end{array}$} \\
\hline & $B$ & SE B & $B$ & SE B & $B$ & SE B & $B$ & SE B \\
\hline & 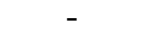 & & & & & & & \\
\hline Treat $\times$ Post & $0.04 * *$ & 0.02 & & & $-0.04 *$ & 0.02 & & \\
\hline Treat & 0.01 & 0.01 & 0.01 & 0.01 & 0.01 & 0.01 & 0.01 & 0.01 \\
\hline Post & -0.03 & 0.02 & & & -0.03 & 0.02 & & \\
\hline Treat x 2007 & & & 0.00 & 0.03 & & & 0.01 & 0.03 \\
\hline Treat x 2008 & & & $-0.07 *$ & 0.03 & & & $-0.06 *$ & 0.03 \\
\hline Treat x 2009 & & & $-0.06 *$ & 0.02 & & & $-0.05 *$ & 0.02 \\
\hline Treat x 2010 & & & -0.05 & 0.03 & & & -0.04 & 0.03 \\
\hline Treat x 2011 & & & -0.04 & 0.02 & & & -0.03 & 0.02 \\
\hline $\mathrm{R} 2$ & 0.03 & & 0.03 & & 0.01 & & 0.01 & \\
\hline $\mathrm{N}$ & 4,655 & & 4,655 & & 4,655 & & 4,655 & \\
\hline
\end{tabular}

Note: Models 2 and 3 include full year dummies and controls for age, age-squared, number of children, years of education and years work experience; $* \mathrm{p}<0.05 * *$ $\mathrm{p}<0.01$.

\section{Appendix Table 11 I mpact of QPI P on Mothers' (In) Hourly wages, variations on Models 2 and 3}

\begin{tabular}{|c|c|c|c|c|c|c|c|c|}
\hline & \multicolumn{2}{|c|}{$\begin{array}{l}\text { Model } 2 \text { without } \\
\text { number of } \\
\text { children }\end{array}$} & \multicolumn{2}{|c|}{$\begin{array}{c}\text { Model } 3 \text { without } \\
\text { number of } \\
\text { children }\end{array}$} & \multicolumn{2}{|c|}{$\begin{array}{l}\text { Model } 2 \text { without } \\
\text { education or } \\
\text { work experience }\end{array}$} & \multicolumn{2}{|c|}{$\begin{array}{l}\text { Model } 2 \text { without } \\
\text { education or } \\
\text { work experience }\end{array}$} \\
\hline & $\mathrm{B}$ & SE B & $B$ & SE B & $B$ & SE B & $B$ & SE B \\
\hline Treat $\times$ Post & $\begin{array}{c}0.04 * \\
-\end{array}$ & 0.02 & - & & $\begin{array}{c}0.02 \\
-\end{array}$ & 0.03 & - & \\
\hline Treat & $0.06 * *$ & 0.02 & $0.06 * *$ & 0.02 & $0.08 * *$ & 0.02 & $0.08 * *$ & 0.02 \\
\hline $\begin{array}{l}\text { Post } \\
\text { Treat } x\end{array}$ & $0.07 *$ & 0.03 & & & $0.10 * *$ & 0.03 & & \\
\hline $\begin{array}{l}2007 \\
\text { Treat x }\end{array}$ & & & 0.03 & 0.05 & & & 0.05 & 0.05 \\
\hline $\begin{array}{l}2008 \\
\text { Treat } x\end{array}$ & & & 0.02 & 0.04 & & & -0.00 & 0.04 \\
\hline $\begin{array}{l}2009 \\
\text { Treat } x\end{array}$ & & & 0.03 & 0.04 & & & 0.00 & 0.04 \\
\hline $\begin{array}{l}2010 \\
\text { Treat } x\end{array}$ & & & 0.06 & 0.04 & & & 0.03 & 0.04 \\
\hline 2011 & & & 0.06 & 0.03 & & & 0.02 & 0.04 \\
\hline $\mathrm{R} 2$ & 0.34 & & 0.34 & & 0.19 & & 0.19 & \\
\hline $\mathrm{N}$ & 4,665 & & 4,665 & & 4,665 & & 4,665 & \\
\hline
\end{tabular}

Note: Models 2 and 3 include full year dummies and controls for age, age-squared, number of children, years of education and years work experience; * $\mathrm{p}<0.05 * *$ $p<0.01$. 